\title{
Do Directors Have a Use-By Date? Examining the Impact of Board Tenure on Firm Performance
}

\author{
Joshua Livnat \\ New York University \\ QMA \\ Gavin Smith \\ QMA \\ Kate Suslava \\ Bucknell University \\ Martin Tarlie \\ GMO
}

Corporate boards serve the important functions of monitoring and advising management. We examine whether boards consisting of longer-serving directors are better able to fulfill these functions due to firmspecific knowledge accumulation, or whether director performance suffers due to declining effectiveness in monitoring managers. Our evidence suggests that board tenure is positively related to forward-looking measures of market value and stock returns, with the relationship reversing after about nine years on average. The detrimental effect of tenure is stronger for high growth firms, which is consistent with the deterioration of the board members' ability to perform their advisory functions.

\section{INTRODUCTION}

The length of time directors stay on board ("board tenure") is a controversial issue that has attracted the attention of professional investors, regulators, and academics. The call by institutional investors for board "refreshment" - allowing new members to enter the board - is driven by the desire for a more diverse mix of board members and by the conventional wisdom that long-serving board members become entrenched. The thinking is that entrenchment leads to cozy relationships between board members and executives, thereby diminishing the ability of board members to effectively represent shareholders' interests. A regulatory solution to this issue would be to limit director tenure by imposing a tenure limit.

The corporate governance literature that examines the relationship between board tenure and firm market value is characterized by inconsistent findings. Some studies find that longer board tenure is detrimental to firm value, as it leads to the decrease of board independence (Vafeas 2003), governance problems (Berberich 2011), and lack of critical thinking by board members (Coles et al. 2015). On the 
other hand, a different stream of literature finds that board tenure is improving board's functionality, as longer-tenured board members are less susceptible to pressure by managers (Beasley 1996, Schnake et al. 2005), are more knowledgeable about company operations (Rutherford 2007), and are more likely to curb opportunistic behavior by managers (Hamouda et al. 2013 and Dou et al. 2015). One potential reason for the inconsistent empirical findings may be related to the small samples used by these studies. Most existing studies are limited to case studies, extreme cases (e.g. companies with fraud or financial statement restatements), and specific industries. Another possible explanation for the inconsistent results is the inherent endogeneity of board selection, as board members might prefer to stay longer on boards of a better-performing companies, or shareholders of good companies might be reluctant to refresh a board when things are not "broken".

In this paper, we view board tenure as a measure of how stable a certain mix of director capital has been, and study how it impacts board effectiveness in value creation through its advisory and monitoring functions. On one hand, longer board tenure signals that the shareholders have appointed and maintained a board with the relevant mix of board capital. Therefore, an increasing tenure of a board can be viewed as a proxy for an able and well-functioning board that is positively contributing to firm value. However, even if a board has a relevant mix of capital to perform its duties effectively, board's ability might be diminished by the board's incentives to monitor managers. As board members' tenure increases, they become more connected to the firm's management and less motivated to effectively monitor managers. In addition to the indirect effect of board tenure on monitoring incentives, board tenure might have a direct effect on the relevance of board capital. With time, as a firm is changing, board capital might become stale and less relevant to the needs of the firm. Therefore, extreme values of board tenure can be signaling both boards' disincentives to effectively monitor management and the staleness of board capital. This can lead to the negative impact of board tenure on firm value, and this latter effect is likely to be especially pronounced for fast-growing firms, where changing firm needs and strategic directions may cause faster deterioration of board capital.

In our study, we consider the relationship between board tenure and firm market value, as measured by both market-to-book ratio and stock returns. We study this relationship using an extensive sample of U.S. firm over 1996-2016. We find that longer average board tenure is positively related to both contemporaneous and future market-to-book. However, this relationship reverses at a certain point, roughly after eight to nine years of average board tenure. Beyond this "benchmark" for the average board tenure, we observe a deterioration in valuation that is especially significant for growing firms. For the stock return-based tests, we find that board tenure is reflected in stock returns in a similar manner to market values, and that the declining effect of long board tenure is similarly more pronounced for dynamic, growing firms. We also find that an investment strategy that holds long positions in stocks of companies with long board tenure (more than 12 years of average tenure) and short positions in companies with short board tenure (less than two years of average tenure) earns statistically significant abnormal returns ranging between 0.49 and 0.70 percent per month.

Our results confirm and extend a study by Huang and Hilary (2018), who find that firm value, measured by Tobin's Q, has an inverted U-shape for groups of companies sorted on the length of board tenure. Our most important contribution is to show that the relationship between board tenure and firm value is reflected in two forward-looking measures of equity value - next-period market-to-book and next month abnormal returns. By using forward-looking measures of firm value and stock returns we are also mitigating the endogeneity problems inherent in prior studies. Additionally, we disentangle the effect of tenure on the board's ability (board capital) by showing how a company's growth options determine the relationship between board tenure and firm value. We show that firm attributes, such as its growth rate, impacts the optimal average board tenure, suggesting that a uniform regulation limiting board tenure across companies and at all times may not be desirable. Finally, we have the largest sample used to-date to test the relevance of board tenure - up to 3,800 individual firms over a 20-year period.

The remainder of our paper is organized as follows. Section II discusses the prior literature in the area, and Section III follows with hypotheses development. In Section IV, we describe the research design 
and the data used in the study. Section V presents the empirical results, with Section VI providing additional robustness tests on the relationship of firm value and board tenure. Section VII concludes.

\section{PRIOR LITERATURE}

There is a substantial literature on the importance of tenure in explaining the performance of decision makers in different professions. For mutual fund managers, Chevalier (1999) finds that longer tenure helps them retain their job, as these managers are less likely to be terminated based on their performance, compared to younger portfolio managers. This "entrenchment" of longer-tenured managers stems from their higher than average performance early in their career: in effect, they are branded as having superior skills and abilities going forward. However, their outperformance is mainly due to chance and later results in mean reversion (Porter et al. 2012). For credit analysts, tenure matters when it comes to their tenure covering specific firms for the rating agency: their optimism increases and accuracy decreases with tenure covering the firm (Fracassi et al. 2015). Auditors' tenure contributes to firm value up to a certain point in time, as reflected in equity risk premium, with the relationship reversing at the extreme values of tenure (Boone et al. (2008). CEO tenure is negatively affecting firm performance in dynamic industries because prolonged-tenure CEOs tend to develop a relatively fixed paradigm of managing the firm and unwillingness to accept new information or initiate strategic changes (McClelland et al. 2012). Politicians seem to be more effective in later periods of their tenure, as elections draw nearer. Ghosh (2006) finds that both property crimes and violent crimes in India go up in the initial years of an incumbent politician's tenure and then decline in the later periods of their tenure, closer to re-election. Tenure does not seem to matter when it comes to academic performance. For example, Li et al. (2010) find that the productivity (total number of papers) and impact (citations of papers) of the economics and finance faculty from top twenty-five schools remains consistent before and after they attain tenure.

Prior literature looks for evidence that board tenure is a board characteristic that can have an impact on firm performance and firm value by influencing the director monitoring or advising functions. Empirical papers find contradictory results about the relationship between tenure and board's monitoring function. Some researchers argue that seasoned board members over time become friendlier with managers and lose their ability to objectively examine managers' actions, thus decreasing the level of board independence and contributing to the erosion of firm value. Board tenure is thus viewed as a proxy for the extent to which outside directors are affiliated with management. For example, Vafeas (2003) claims that, in time, directors might be co-opted by managers when directors become less mobile and less attractive to other companies. He finds that directors who stay on the board the longest are significantly more likely to have a fiduciary relation with the firm (so called "grey directors" - bankers, consultants, lawyers), are more likely to be affiliated with managers from the beginning of their board tenure, and tend to have more power and more equity ownership in the firm. Finally, he finds that this lack of independence is positively related to the amount of CEO's salary. Following similar argument about the increasing lack of oversight by complacent board members, Berberich et al. (2011) find a positive association between director tenure and the probability that a company will experience some governance problems, such as bankruptcies, major litigations, major accounting restatements, or corporate scandals.

On the other hand, another stream of literature argues that longer-tenured board members are in a better position to scrutinize senior managers because they are less susceptible to peer pressure and are less likely to be controlled by managers. Two event studies examine firms with corporate governance problems: Beasley (1996) looks at firms with cases of fraud while Schnake et al. (2005) examine firms with 10-K investigations. Both studies find that longer board service increases the outside directors' ability to monitor managers more effectively to prevent fraud or 10-K investigations. An association study by Sharma (2011) examines the role of board tenure in controlling managerial discretion over the use of excess cash flow as measured by the dividend payout policy. She argues that dividend policy is one area where conflicts between management and shareholders may occur and the board is the ultimate internal governance mechanism charged with protecting shareholders' interests. She finds that the tenure of independent directors is positively related to the likelihood of a dividend payout. Bonini et al. (2015) 
find some evidence that longer-tenured board members (with tenure over 20 years) are better at monitoring management actions because they gather and store valuable information about the firm and can share it with other independent directors. They find that such firms are more profitable and have higher market value.

Similarly, researchers that examine how tenure affects the board's advisory function find inconsistent results. On one hand, an argument is made that longer tenure of board members allows them to learn more information about the operations of the company, making it easier for them to understand the firm's unique economic environment and financial reports, resulting in their improved ability to provide more informed advice to the management team. This, in turn, should result in a better-run firm. Studies that examine information-gathering practices of board members provide some support for this line of argument. For example, Rutherford et al. (2007) find that longer-tenured boards exchange information more frequently, as measured by the number of board committees. Additionally, a group of studies provide empirical evidence that better informed boards, as proxied by board tenure, provide better advice to managers that enhances the value of the firm. For instance, Muller-Kahle et al. (2011) show that financial service companies that chose to specialize in subprime lending and, and as a result, were negatively affected by subprime loan defaults had board members with less tenure, as compared to "smart" firms that avoided these risky business practices. Howton (2006) finds that firms with longer tenure boards are more likely to survive after an IPO vs. firms that fail or are acquired, and Hamouda et al. (2013) show that more seasoned boards are more likely to curb predatory insider trading practices around share repurchase announcements.

On the other hand, some studies of the relation between tenure and advisory function of the board hypothesize that board members might become complacent and stop learning about the firm's operations the longer they stay on board. For instance, Coles et al. (2015) introduce a measure of groupthink - a way of thinking by cohesive groups where peer-pressure overrides the need for critical thinking. In the study groupthink is proxied by the length and the degree of overlap of board tenure. The study does not find support for the blanket prediction that groupthink has a negative effect on value for all types of firms, as measured by contemporaneous Tobin Q. However, the study does find evidence that the effect of groupthink on firm value is negative in dynamic industries, firms with smaller boards, and in firms that have boards with fewer outside connections. This is consistent with the idea that, holding group cohesion constant, the tendency to suffer from groupthink is harder to overcome in smaller boards and in boards with fewer outside connections.

Several studies in the area look at the interaction of both monitoring and advisory functions with board tenure and study how it is reflected in firm value. Huang and Hillary (2018) find that the relationship between board tenure and contemporaneous firm value (measured by Tobin Q) is in the shape of an inverted $U$ that reaches a peak at about nine years. They find that the value of companies initially rises, as directors acquire firm-specific knowledge early in their tenure. However, this continues only up to a certain threshold of tenure beyond which independence losses outweigh the learning gains and board tenure becomes detrimental to firm value. Dou et al. (2015) find that directors' performance improves with extended tenure. They find that longer-serving directors have a higher level of commitment, are better at controlling CEO turnover and CEO pay, have lower likelihood of intentionally misreporting earnings, and are also more likely to restrict the expansion of resources under CEO control (acquisitions are rarer and of higher quality).

\section{HYPOTHESIS DEVELOPMENT}

We examine the relationship between board tenure and firm value within the framework developed by Hillman and Dalziel (2003) that considers both the direct effect of board capital on the monitoring and advisory functions of the board and the moderating effect of board incentives. Boards have two main functions: monitoring management on behalf of shareholders (monitoring function) and providing resources to the firm (advisory function). Effective monitoring by the boards lowers agency costs which in turn results in enhanced firm value (Fama 1980). Provision of resources by the board contributes to 
firm value by helping reduce dependency between the organization and external contingencies, diminish uncertainty for the firm, and lower transaction costs (Pfeffer and Salancik 1978). In order to be able to perform the two functions well, a board needs relevant board capital that consists of human capital (i.e. expertise, experience, knowledge of board members) and relational capital (i.e. connections that board members have to other organizations, prestige of directors, influence with political organizations, etc.).

While board capital is the board's ability to perform the two main board functions, board incentives influence the efforts that directors exercise in performing these functions. They can motivate board members to, for example, be more proactive in reaching out to their external connections to secure more favorable financing terms for the company. It should be noted that if a director has an incentive, but does not have the ability (for example, a director does not have the right banking connection in the example above), s/he will not be able to perform this board function (i.e. secure good financing terms for the firm). In other words, board members' ability to perform their functions are limited by the board's capital, and board incentives can only moderate boards' effectiveness in performing these functions. Exhibit 1 illustrates the relationship between the components of the theoretical framework described above.

\section{EXHIBIT 1 \\ BOARD OF DIRECTORS AND FIRM VALUE}

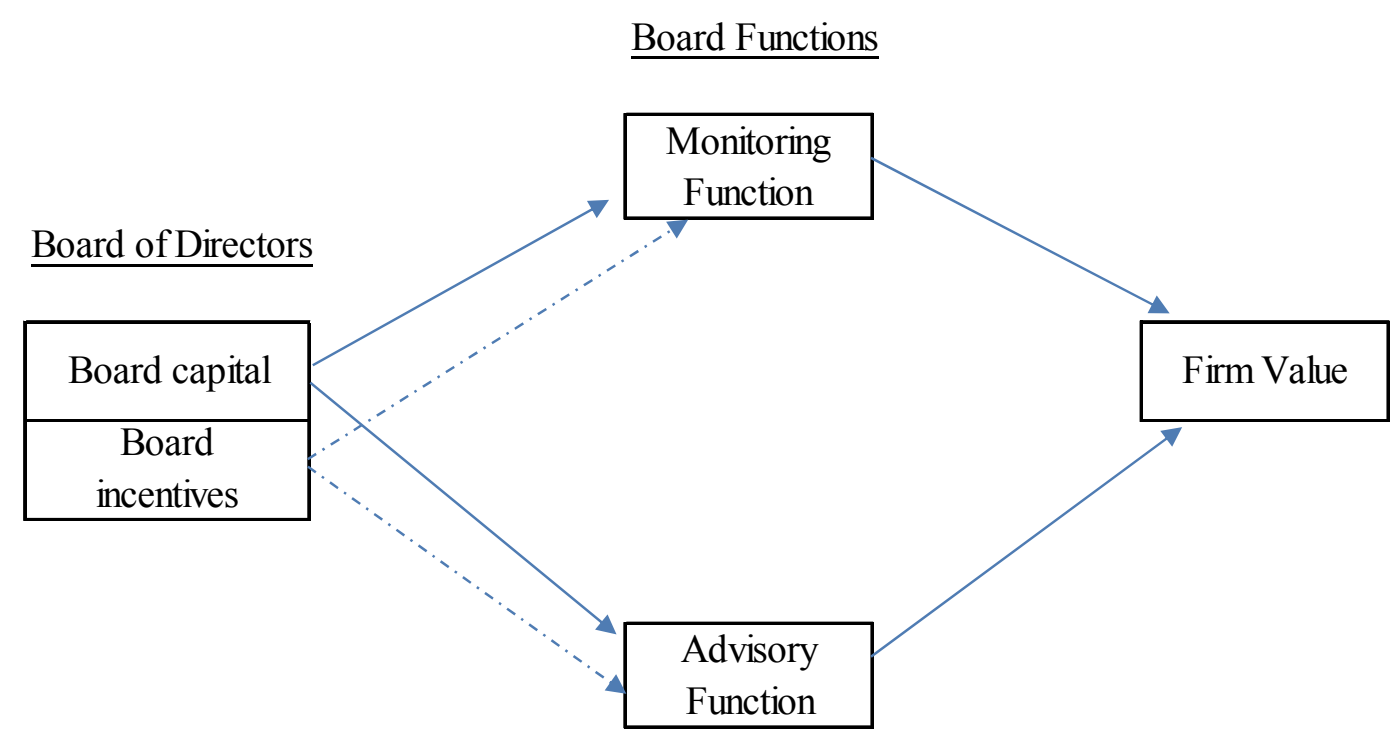

Boards with the relevant capital have the ability to monitor management and provide additional resources for the firm thus contributing positively to firm value. When investors are unhappy with director ability (capital), they refresh the board with a more relevant mix of board capital. Therefore, board tenure is a measure of how long a certain mix of director capital has been unchanged, and, in effect, longer board tenure signals that shareholders have appointed a board with the relevant mix of board capital. Increasing board tenure can be viewed as a proxy for an able and well-functioning board that is positively contributing to firm value. This leads to our first hypothesis in the following form:

Hypothesis 1: Longer board tenure indicates that shareholders have selected board members with appropriate monitoring and resource provision abilities to meet the needs of the firm that contribute to the appreciation of firm value. Therefore, we expect a positive relationship between board tenure and firm value.

Both board capital and incentives determine the board performance. If a board has the ability to perform monitoring, this ability might be enhanced or diminished by board's incentives to monitor 
managers. As board members' tenure increases, they become more connected to the firm's management through business dealings and social connections, and, as a result, more dependent of management. Board dependence on management will then act as a disincentive to monitor managers, negatively affecting the relationship between the boards' ability to monitor and the actual monitoring of management. This, in turn, will lead to the increasing agency costs between managers and owners and will negatively impact shareholder value. In addition to the indirect effect of board tenure on monitoring incentives, board tenure might have a direct effect on the relevance of board capital. With time, as a firm is changing, board capital might become stale and less able to meet the needs of the firm. Without refreshing the board capital in time, shareholders might be running the risk of ending up with a mix of board capital that no longer meets the needs of the firm. Therefore, extreme values of board tenure can be, on one hand, signaling boards' disincentives to effectively monitor management and, on the other hand, the staleness of board capital. This leads to our second hypothesis:

Hypothesis 2: Beyond certain tenure threshold, we expect a reversal in the relationship between board tenure and firm value as board member's capital becomes stale and board's dependence on firm management creates disincentives for board members to monitor managers.

As we have outlined above, board capital determines its ability to perform its two main functions. In equilibrium, board capital maximizes firm value by providing required monitoring and advising services for a particular firm. However, as a firm changes its business strategy, shareholders will need to "rebalance" board capital and possibly appoint new board members that have the most appropriate human and relationship capital to meet the new needs of a firm. We expect that this rebalancing of board capital should happen more frequently for fast-growing firms, and those firms that do not rebalance in time will suffer from the deterioration in firm value. This reasoning leads to our third hypothesis:

Hypothesis 3: The reversal of the positive relationship between board tenure and firm value is more pronounced for fast-growing firms.

\section{SAMPLE AND RESEARCH DESIGN}

\section{Sample Selection}

The board data in this study is from the Capital IQ database for 1996 to 2016. It is extracted from the CIQ_Professional table, which includes data about professionals associated with various organizations. We first extract all observations with a valid CompanyID (it is used to link to the Compustat and CRSP databases), a valid PersonID (it links the individual across years and companies), and a valid start date. We identify board members as individuals with the following titles (Profunctionname in the table): "Chairman of the Board", "Co-Chairman of the Board", and "Member of the Board of Directors". We restrict our sample to independent board members only, i.e. those who are unemployed by the firm. For each director-year observation, we then calculate the length of director board tenure. If an individual was elected to the board, for instance, in 1998, we use 1998 to calculate that person's tenure in 1999 (one year later) and onwards. This way, in 2005 that person's tenure is seven years.

The dataset includes additional items such as director age, the ending date for the director position, whether the individual is a current board member, and the year in which the firm was founded. If the ending date is missing and the individual is a current board member, we set the end-year to be 2017. If the ending date is missing and the individual is not a current board member, we set the end-year to equal the start year. We delete observations where the start year is earlier than the year the firm was founded or prior to 1945. To test the accuracy of the sample data, we examine the data for four companies, two large and two small, in the late 1990's and in the late 2010's against the proxy statements available in the SEC EDGAR database. We found a very high accuracy for the latter years, and some missing board members (less than 25 percent) for the early years. 
We obtain accounting data from the Compustat Point-in-Time database and stock return data from the Center for Research in Security Prices (CRSP) database. We require all companies in our sample to be incorporated in the US, have a positive book value and to be founded at least five years before we begin tracking their board tenure. To reduce the bias caused by smaller firms, we require a market value in excess of $\$ 100$ million, and a minimum of three independent members on the board. Throughout our research we standardize accounting and stock return variables to a normal distribution, bound between plus and minus three to deal with outliers in the data. As a robustness check, we re-perform our tests using winsorized variables and the results are unchanged. For all other level-based variables we use the natural logarithm to manage outliers.

\section{Research Design}

To test our hypotheses, we focus on the relationship between board tenure and two measures of firm performance: 1) firm value, as proxied by market-to-book; and 2) stock returns.

\section{Firm Value and Board Tenure}

We examine the relationship between firm value and board tenure in both univariate and multivariate settings. For the univariate test, we rank all firms in our sample into deciles based on the average board tenure ("tenure deciles"). We industry-adjust the measure of firm value by subtracting, annually, the median market-to-book for the firm's industry using the Fama-French 48 -industry classification. We then examine the median values of the industry-adjusted market-to-book values across different tenure deciles. Next, we examine the relationship between board tenure and firm value in a multivariate setting. First, we estimate the relationship between board tenure and contemporaneous firm value to test prior findings by researchers on a larger sample of firms. To do this, we estimate variations of the following model:

Market $/$ Book $_{i t}=\beta_{1}$ Tenure $_{i t}+\beta_{2}$ Tenure $_{i t}^{2}+$ Board Controls $_{i t}+$ Firm Controls $_{i t}+\epsilon_{i t}$

We calculate our main variable of interest, Tenure, by taking the average board tenure of all independent board members for each firm for each year. In order to account for the expected nonmonotonic relationship of a particular form of board tenure and market value, we also include a squared Tenure term. We include control variables that capture both firm and board characteristics previously shown to be related to firm value. For board controls we include Board size, the number of independent directors on the board, Average Age, the average age of independent directors on the board, Connections, the average number of boards that directors are serving on, including the current firm board, and Chair $C E O$, an indicator when the CEO also serves as board chair. Yermack (1996) establishes the value relevance of board size. We add Average Age as a control variable to disentangle the effect of board tenure from the director's age. Well-connected boards likely add to firm value by providing better advice to managers, due to for information transmission between companies (Larcker 2013) and their ability to affect business relationships with other firms; Connections controls for this enhanced advisory function due to the board centrality. Goyal and Park (2002) show that CEO duality (Chair CEO) makes it harder for boards to dismiss an ineffective CEO and results in the inferior firm performance.

For firm controls, we use Annual sales (Sales $12 \mathrm{~m}$ ), firm age (Firm Age), and number of business segments (SegNum) to control for size and complexity, which may affect the advisory role of board members. Growth opportunities of the firms are captured by Intangibles (scaled by Total Assets), Leverage (scaled by Total Assets), and $R \& D$ intensity (scaled by Sales). Firm profitability is controlled by two $R O A$ variables - one for current and one for next period. We also include standard deviation of daily stock returns during the prior calendar year (StdRet), as a proxy for firm stability. We rely on prior studies to select firm and board controls, such as Hermalin and Weisbach (1988), Denis and Sarin (1999), Bhagat and Black (2001), and Baker and Gompers (2003).

Model (1) is first estimated as a panel regression with industry and year fixed effects. Next, to examine the stability of the relationship between board tenure and firm value through time, we run cross- 
sectional regressions annually and calculate the time-series average of the coefficients and report $\mathrm{t}$ statistics using the time-series standard error of the mean.

A common concern in empirical corporate governance research is the impact of reverse causality. When it comes to board tenure, directors might be interested in staying longer on the boards of better performing firms, or firms with good performance might be reluctant to "refresh" the board, following a do-not-fix-what-ain't-broken line of reasoning. As an attempt to address this endogeneity concern we use forward (instead of contemporaneous) values of market-to-book as a dependent variable in model (1) (an approach adopted by Hermalin and Weisbach (1991)). Following Rajgopal and Shevlin (2002), we use contemporaneous values of market-to-book as an additional dependent variable:

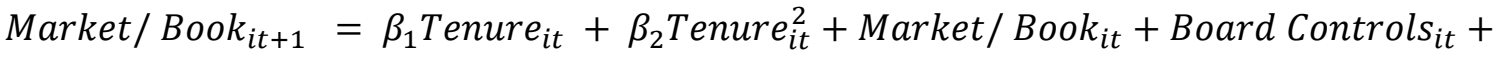

$$
\begin{aligned}
& \text { Firm Controls } i t+\epsilon_{i t}
\end{aligned}
$$

Next, we test the effect of the growth option on the value relevance of board tenure using panel regressions and Fama and MacBeth (1973) style regressions on firm-level data. We modify model (1) by adding an interaction of growth option proxies with a squared Tenure term and by including the growth option proxy as a control variable. Specifically, we estimate:

Market $/$ Book $_{i t}=$

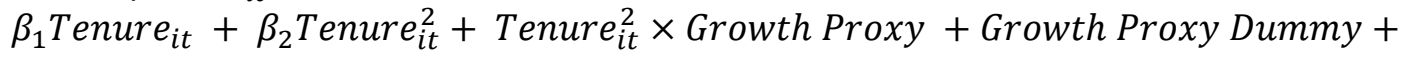
Board Controls $i t+$ Firm Controls $i t+\epsilon_{i t}$

We use four proxies for firm growth options: (i) $R \& D$, an indicator variable equal to one if the firm's ratio of research and development expenses to sales is over the 75th percentile value for all firms for that year. We choose the 75th percentile value because the median R\&D for the firms in the sample is zero. The level of R\&D captures the extent of resources that the company dedicates to development of new products. (ii) SalesGrowth1, an indicator variable equal to one if a firm's sales growth is above the median value of other firms in that year. Sales growth captures the scale of growth experienced by the company. (iii) SalesGrowth3, an indicator variable equal to one if firm's three-year sales growth is above the median value of other firms for the year. We use SalesGrowth3 to capture longer-run growth effects. (iv) Fluidity, an indicator variable equal to one if firm's Fluidity score is above the median value of other firms for the year. Fluidity score is a growth measure developed by Hoberg, Phillips, and Prabhala (2014) and is available from the online data (http://cwis.usc.edu/projects/industrydata/industryconcen.htm). It is derived from the descriptions of general business in the firms' annual financial statements, and it reflects tactics adopted by the competitor firms. Fluidity score is higher when the words in the firm's business description overlap more with the words of the rivals' business description. Hoberg et al. (2014) argue that fluidity scores capture changes in rival firms' products and reflect the pressures firms face from the competitor firms.

\section{Stock Returns and Board Tenure}

In our second set of tests, we investigate the relationship between board tenure and stock returns. All of these return-based tests focus on the ability of board tenure to explain future one-month abnormal stock returns. Evaluating the ability of board tenure to explain future stock returns is a strong test to further address concerns surrounding causality and endogeneity.

First, we perform simple univariate sorts of stocks based on board tenure, and examine the pattern of excess stock returns. This allows us to examine any linear and non-linear relationships between board tenure and future stock returns. Each month we separate all firms into quintiles and deciles based on Tenure. We carry forward the board tenure measure computed at the end of a calendar year over the next 12 months. We use three different measures of abnormal stock returns. First, $X \_R E T$ is the excess stock return, defined as the monthly raw stock return in excess of the capitalization-weighted market return. 
Second, DGTW_RET is the characteristic adjusted excess return of a stock computed using the Daniel et al. (1997) methodology. In Daniel's approach, DGTW_RET is the buy and hold return on a security minus the capitalization-weighted average buy and hold return on a portfolio of firms with similar size (three groups), B/M (three groups) and 11-month momentum (three groups). Third, FF_RET is a measure of risk-adjusted return, defined as the intercept of a four-factor model that includes three Fama-French factors and momentum (see Fama and French (1993) and Carhart (1997)):

$R p_{t}-R f_{t}=a+b \cdot\left[R m_{t}-R f_{t}\right]+s \cdot S M B_{t}+h \cdot H M L_{t}+u \cdot U M D_{t}+e_{t}$

Second, we examine the relationship between firm abnormal returns (DGTW_RET) and board tenure in a multivariate setting. We use a Fama and MacBeth (1973) style regression model, including the previously described board and firm controls:

$D G T W_{-} R E T_{i t+1}=\beta_{1}$ Tenure $_{i t}+\beta_{2}$ Tenure $_{i t}^{2}+$ Board Controls $_{i t}+$ Firm Controls $_{i t}+\epsilon_{i t}$

Each month end, we estimate the cross-sectional regression Model (5). We then calculate the timeseries average of the coefficients and report t-statistics using the time-series standard error of the mean coefficient.

In our third set of stock return tests, we examine the value relevance of board tenure for predicting stock returns of high growth firms using Fama-MacBeth regressions on firm-level data:

$$
\begin{aligned}
& \text { DGTW }_{\text {RET }} \text { it }+1 \\
& \beta_{1} \text { Tenure }_{i t}+\beta_{2} \text { Tenure }_{i t}^{2}+\text { Tenure }_{i t}^{2} \times \text { Growth Proxy }+ \text { Growth Proxy Dummy }+ \\
& \text { Board Controls }_{i t}+\text { Firm Controls }_{i t}+\epsilon_{i t}
\end{aligned}
$$

We use five proxies for firm growth options similar to Model (3) and add Market-to-Book as an additional proxy for growth. Market-to-Book is defined as an indicator variable equal to one if firm's market-to-book ratio is above the median value of other firms for the year. Market-to-book ratio is higher for high growth firms as market price is factoring a higher expected future growth for the firm and a higher return on its assets.

\section{RESULTS}

\section{Summary Statistics}

Figure 1 plots the firm-year observations for our sample. Our final sample comprises of 638,717 firmmonth observations, with 1,335 individual firms at the beginning of our sample period (year 1996) going up to 3,802 in 2006 and coming down after the financial crisis to 3,152 individual firms in 2016. 
FIGURE 1

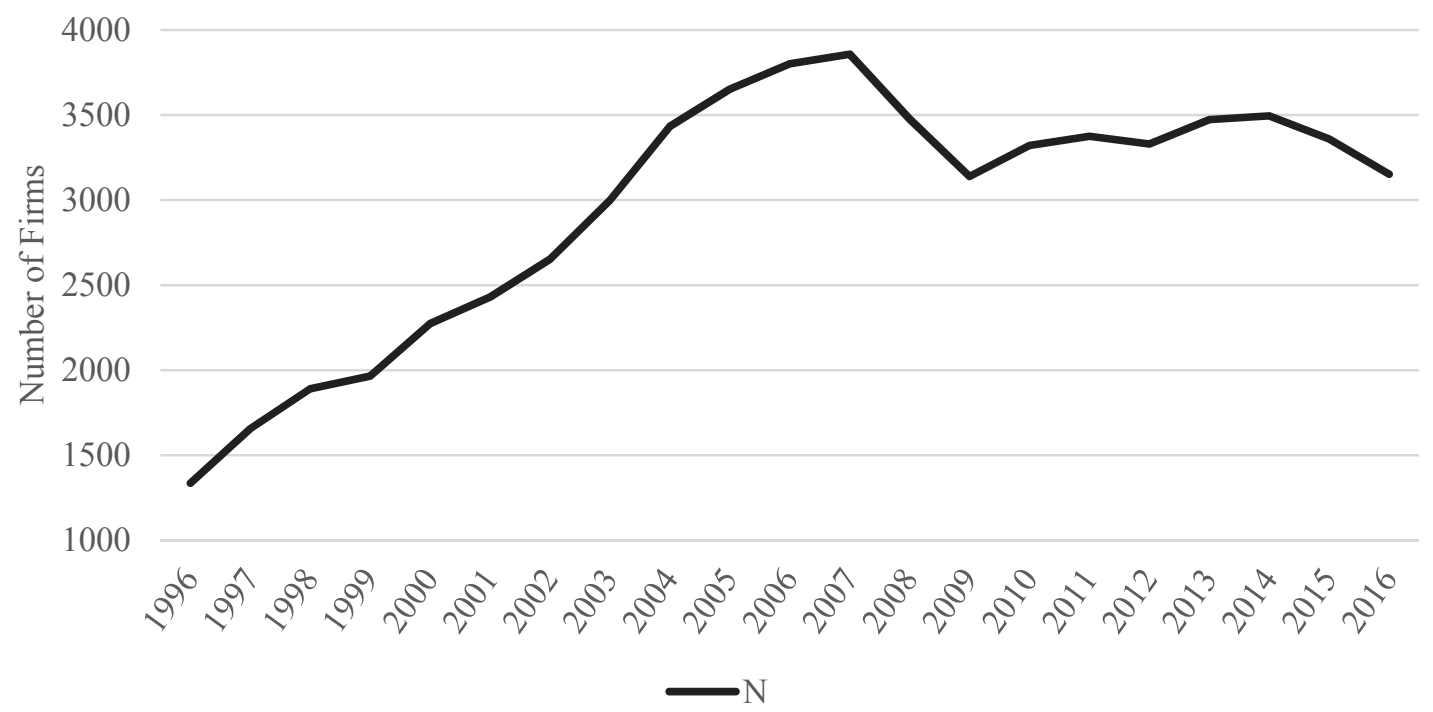

Table 1 presents important firm and board characteristics of companies in our sample. An average independent director serves on the board for six years (Tenure has 6.7 mean and 6.0 median), is 58 years old, and sits on three boards (mean for Connections is 2.80). Boards have seven independent directors on average and in about $36 \%$ of firms the CEO also serves as board chair. Our sample firms are large, with average market capitalization of $\$ 5.9$ billion and sales of $\$ 4.4$ billion.

TABLE 1

DESCRIPTIVE STATISTICS AND CORRELATIONS

Panel A: Descriptive statistics

\begin{tabular}{|c|c|c|c|c|c|c|c|}
\hline & $\mathrm{N}$ & Mean & Median & Std Dev & p25 & p75 & Correlation \\
\hline \multicolumn{8}{|l|}{ Board Characteristics } \\
\hline Tenure (years) & 638,717 & 6.65 & 6.00 & 3.89 & 3.83 & 8.83 & \\
\hline Med Tenure (years) & 638,717 & 5.95 & 5.00 & 4.14 & 3.00 & 8.00 & $0.8676 * * *$ \\
\hline Std Tenure (years) & 638,717 & 4.94 & 4.32 & 3.31 & 2.50 & 6.73 & $0.7763 * * *$ \\
\hline Average Age (years) & 638,717 & 58.55 & 58.86 & 6.21 & 55.20 & 62.14 & $0.4681 * * *$ \\
\hline Board Size & 638,717 & 7.00 & 7.00 & 2.86 & 5.00 & 9.00 & $0.1838 * * *$ \\
\hline Connections & 638,717 & 2.80 & 1.80 & 0.78 & 1.33 & 2.44 & $-0.0973 * * *$ \\
\hline Chair CEO & 638,717 & 0.36 & 0.00 & 0.48 & 0.00 & 1.00 & $0.0651 * * *$ \\
\hline \multicolumn{8}{|l|}{ Firm Characteristics } \\
\hline Market cap & 638,717 & 5911.50 & 805.02 & 21551.44 & 290.64 & 2953.73 & $0.0634 * * *$ \\
\hline Book value & 638,717 & 2666.34 & 392.85 & 10737.63 & 139.53 & 1329.40 & $0.0939 * * *$ \\
\hline Book-to-market & 638,717 & 0.54 & 0.48 & 1.72 & 0.27 & 0.72 & $0.0652 * * *$ \\
\hline RET & 638,717 & 0.01 & 0.01 & 0.14 & -0.05 & 0.06 & $0.0207 * * *$ \\
\hline DGTW RET & 638,717 & 0.00 & 0.00 & 0.13 & -0.05 & 0.05 & $0.0221 * * *$ \\
\hline StdRet & 638,717 & 0.03 & 0.02 & 0.02 & 0.02 & 0.03 & $-0.1962 * * *$ \\
\hline Firm Age (years) & 638,717 & 45.72 & 28.00 & 42.42 & 15.00 & 67.00 & $0.3422 * * *$ \\
\hline Sales & 584,353 & 4467.86 & 657.95 & 18075.20 & 193.82 & 2379.10 & $0.0788 * * *$ \\
\hline SegNum & 501,810 & 2.61 & 2.00 & 1.83 & 1.00 & 4.00 & $0.1063 * * *$ \\
\hline Intangibles & 558,489 & 0.76 & 0.85 & 0.24 & 0.63 & 0.95 & 0.0025 \\
\hline Leverage & 584,353 & 0.25 & 0.19 & 0.19 & 0.04 & 0.37 & $-0.0334 * * *$ \\
\hline $\mathrm{ROA} t$ & 638,717 & 0.09 & 0.10 & 0.17 & 0.04 & 0.16 & $0.0657 * * *$ \\
\hline ROA $t-1$ & 638,717 & 0.09 & 0.10 & 0.17 & 0.04 & 0.16 & $0.0687 * * *$ \\
\hline
\end{tabular}


Growth Proxies

\begin{tabular}{|c|c|c|c|c|c|c|c|}
\hline R\&D & 584,353 & 0.06 & 0.00 & 0.18 & 0.00 & 0.03 & $-0.1159 * * *$ \\
\hline Sales Growth1 & 616,007 & 0.13 & 0.09 & 0.25 & 0.00 & 0.22 & $-0.1347 * * *$ \\
\hline Sales Growth3 & 616,007 & 0.56 & 0.31 & 0.77 & 0.05 & 0.83 & $-0.2061 * * *$ \\
\hline Fluidity & 475,358 & 7.33 & 6.60 & 3.94 & 4.49 & 9.37 & $-0.1578 * * *$ \\
\hline Market-to-Book & 638,717 & 6.30 & 2.15 & 3.12 & 1.38 & 3.67 & $-0.0572 * * *$ \\
\hline
\end{tabular}

Panel B: Correlations for Growth Proxies

\begin{tabular}{lccccc}
\hline & R\&D & Sales Growth1 & Sales Growth3 & Fluidity & Market-to-Book \\
\hline R\&D & 1 & & & & \\
Sales Growth1 & $0.0882^{* * *}$ & 1 & & & \\
Sales Growth3 & $0.1121^{* * *}$ & $0.6031^{* * *}$ & 1 & & \\
Fluidity & $0.2105^{* * *}$ & $0.1038^{* * *}$ & $0.1487^{* * *}$ & 1 & \\
Market-to-Book & $0.2664^{* * *}$ & $0.2357^{* * *}$ & $0.2138^{* * *}$ & $-0.0181^{* * *}$ & 1 \\
\hline
\end{tabular}

The table below provides descriptive statistics for our key variables. The sample consists of all firms on Capital IQ database for the years 1996-2016. The board information is from Capital IQ, financial information is from Compustat, and market information is from the CRSP database. Tenure is the average of the tenure of all independent directors sitting on the board. An individual director's tenure is calculated as the year of annual meeting minus the start year of directorship minus any breaks in the service of directorship. Med Tenure is the median of the tenure of all independent directors sitting on the board. Std Tenure is the standard deviation of the tenure of all independent directors sitting on the board. Average Age is the average age of board members. Board Size is the number of directors. Connections is the average number of boards the board members serve on (including the firm observation). Chair CEO is an indicator variable that equals to one when the CEO also serves as board chair, zero otherwise. Market cap is the market value of equity. Book value is the book value of equity. Book-to-market is book value of equity divided by the market value of equity. RET are the one-) and 11-month momentum ( 3 groups). StdRet is the standard deviation of daily stock returns during the prior calendar year. Firm Age (years) is the number of years since the firm is first listed in CRSP database. Sales are 12-month sales for a company. SegNum is the number of business segments. Intangibles are total intangible assets divided by lagged total assets. Leverage is longterm and short-term debt divided by lagged total assets. ROA is operating income before depreciation over the prior four quarters divided by lagged total asset. $R \& D$ is research and development expenditures from the prior four quarters divided by sales from the prior four quarters. Sales Growth1 is the growth in the most recent four quarters of sales over the previous four quarters. Sales Growth3 is growth of the most recent four quarters of sales over the corresponding period three years ago. Fluidity is the fluidity score obtained from the online data (http://cwis.usc.edu/projects/industrydata/industryconcen.htm) provided by Hoberg and Phillips. Market-to-book is market value of equity divided by book value of equity. The Correlation column reports correlation between board tenure and other variables. $* * *, * *, *$ denote significance at $1 \%, 5 \%$ and $10 \%$ level.

Examining the correlations of Tenure with firm characteristics, we note that firms with longer-tenured board members are older (correlation of 34 percent with Firm Age), more profitable (7 percent correlation with $R O A$ ) with low-volatile stock returns (negative correlation of 19 percent with StdRet). All this confirms our expectation that board tenure is a proxy for firm stability. The correlation of Tenure and our proxies for firm growth are all negative, which is consistent with the hypothesis that higher Tenure is more damaging to high-growth firms. Panel B reports the correlation between our various proxies for growth: these variables have generally positive correlations with each other.

\section{Board Tenure and Firm Value}

In this section, we test our hypothesis of the effects of board tenure on firm value, proxied by Marketto-Book. We focus on three issues: effect of board tenure on contemporaneous firm value, effect of board tenure on forward-looking measure of firm value, and the effect of board tenure on the value of highgrowth firms. Our analysis for each is discussed below.

For our univariate tests, we rank firms each year into deciles based on the board tenure and examine the values of industry-adjusted Market-to-Book values across the deciles. Figure 2 plots the average and median board tenure values across the deciles. The length of director tenure ranges from less than 2 years (first decile) to more than 14 years (highest decile). 
FIGURE 2

AVERAGE AND MEDIAN BOARD TENURE BY DECILES

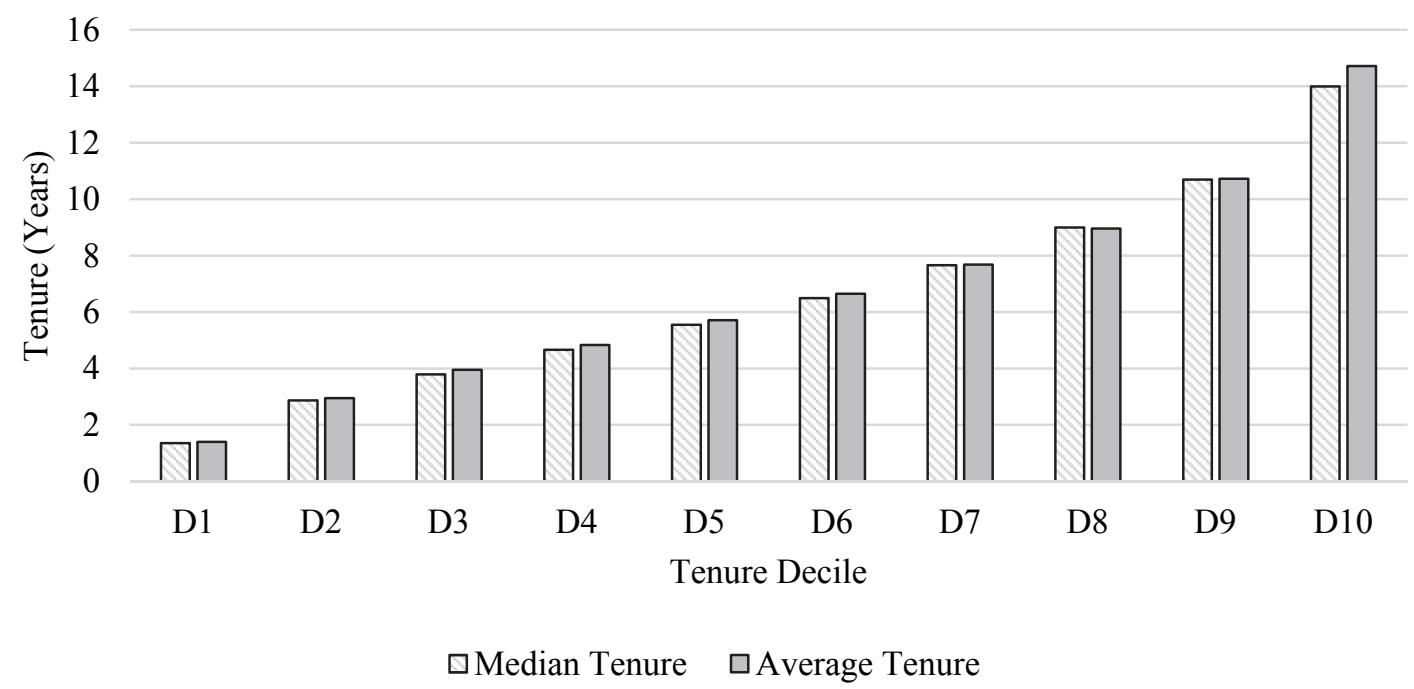

Figure 3 shows how firm values change across the tenure deciles. Initially, firm value is increasing with the length of director tenure: for example, if a firm has a high director turnover (firms in the lowest decile of tenure - D1); it is valued about 5\% lower than other firms in the industry in terms of its marketto-book ratio. However, if directors remain on board for four to five years (D3-D4), firm's valuation is at par with its peers. The highest valuation premium (3\% above the median for the industry) is achieved by the boards with nine years of tenure, after which the valuation ratio starts to decline.

FIGURE 3

MARKET-TO-BOOK SORTED BY TENURE DECILES

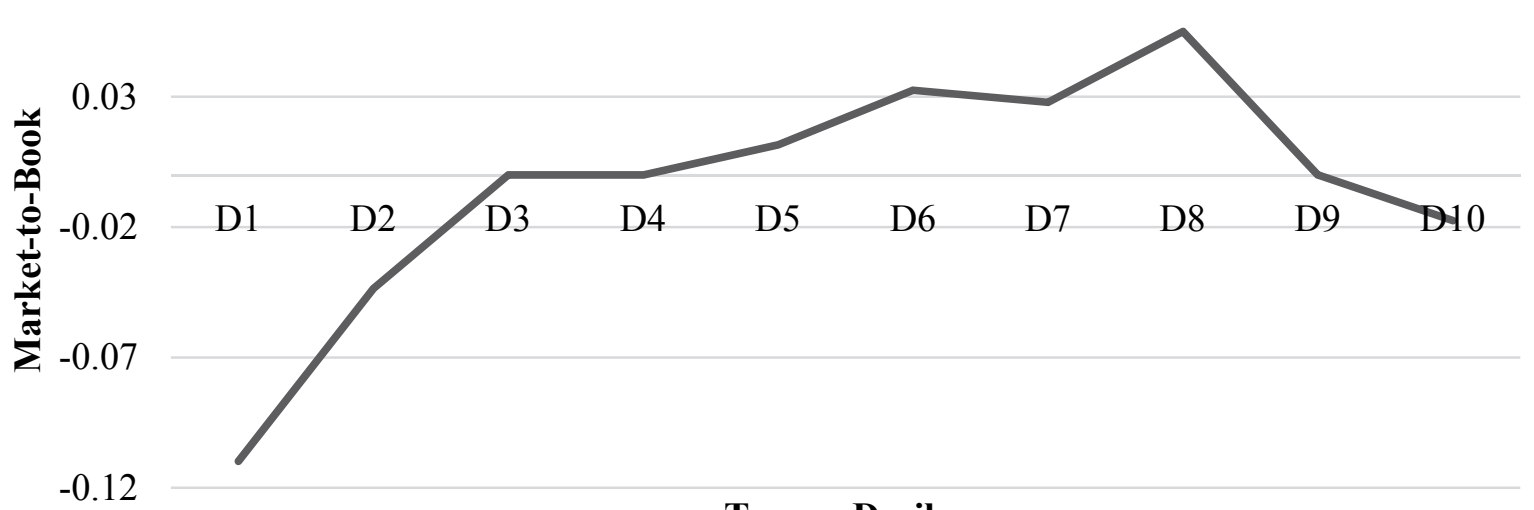

Tenure Deciles

- Market-to-Book (median)

Next, we test our hypothesis in a multivariate setting. Table 2 presents the results of panel regressions for Model (1). In the first specification, we include only board tenure as a dependent variable and observe an insignificant statistical relationship. However, once we include a squared tenure term in the second specification, the coefficient on Tenure become statistically significant and positive, while the coefficient on the squared Tenure term is significantly negative. As we include further controls in regression (3) and 
(4), we see that the coefficients for Tenure and squared Tenure term remain significant at the $1 \%$ level. This confirms our prediction that, on average, board tenure is positively related to firm value, but the contribution to firm value begins decreasing at some point and longer board tenure beyond this critical point becomes a drag on firm valuation.

The coefficients on firm controls in the regression are consistent with our expectations: controls for size (Sales, SegNum) are negative and significant, while controls for growth (Intangibles, Leverage, $R \& D$, and $R O A$ ) are positive and significant. Consistent with our expectations, StdRet, our additional control for stability, is negative and significant. Turning to board controls, we find that Average Age is negatively related to market value, which is consistent with the expected associations in the corporate governance literature that older directors are less active in monitoring managers' performance (e.g., Core et al. 1999). For Board Size we observe a positive relationship, contrary to the association established by Yermack (1996), which can be explained by the differences in the time frame between our studies. We observe a positive and significant coefficient for Connections, which is consistent with findings by Larcker (2013). Companies that have a CEO who is also a chair of the board seem to be valued higher: the coefficient on Chair CEO is positive and significant. This finding contradicts Goyal and Park 2002, which again might be due to the differences between the sample periods and sample sizes.

\section{TABLE 2 \\ IMPACT OF BOARD TENURE ON CONTEMPORANEOUS FIRM MARKET VALUE}

Panel A: Panel Regression

\begin{tabular}{|c|c|c|c|c|}
\hline & \multicolumn{4}{|c|}{ Dependent Variable $=$ Contemporaneous Market/ Book Ratio (stand.) } \\
\hline & 1 & 2 & 3 & 4 \\
\hline Log (Tenure) & -0.0042 & $0.3105^{* * *}$ & $0.2217 * * *$ & $0.1307 * * *$ \\
\hline & $(-0.43)$ & (6.89) & (5.24) & (2.60) \\
\hline $\log (\text { Tenure })^{2}$ & & $\begin{array}{l}-0.0877^{* * *} \\
(-7.16)\end{array}$ & $\begin{array}{l}-0.0751^{* * *} \\
(\mathbf{- 6 . 5 1})\end{array}$ & $\begin{array}{l}-0.0439 * * * \\
(\mathbf{- 3 . 2 1 )}\end{array}$ \\
\hline Log (Firm Age) & & & $(-0.09)^{-0.0006}$ & $(0.28)^{0.0022}$ \\
\hline Log (Sales) & & & $\begin{array}{l}-0.0449 * * * \\
(-12.71)\end{array}$ & $\begin{array}{l}-0.0813^{* * *} \\
(-\mathbf{1 9 . 2 1})\end{array}$ \\
\hline Log (SegNum) & & & $\begin{array}{l}-0.0557 * * * \\
(-4.77)\end{array}$ & $\begin{array}{l}-0.0465^{* * *} \\
(\mathbf{- 3 . 6 5 )}\end{array}$ \\
\hline Intangibles (stand.) & & & $\left.{ }^{(4.13)}\right)^{0.0323 * * *}$ & $\begin{array}{l}0.0236^{* * *} \\
(\mathbf{2 . 7 3})\end{array}$ \\
\hline Leverage (stand.) & & & $\begin{array}{l}0.0709^{* * *} \\
(\mathbf{1 2 . 7 6 )}\end{array}$ & ${ }^{0.0654 * * *}$ \\
\hline $\mathrm{R} \& \mathrm{D}$ (stand.) & & & $\begin{array}{l}0.3130^{* * *} \\
\text { (33.46) }\end{array}$ & $\begin{array}{l}0.2838^{* * *} \\
(\mathbf{2 7 . 9 2 )}\end{array}$ \\
\hline $\mathrm{ROA}_{t}$ (stand.) & & & $\begin{array}{l}0.4127^{* * *} \\
(\mathbf{4 6 . 1 2})\end{array}$ & $\begin{array}{l}0.4226^{* * * *} \\
(\mathbf{4 3 . 4 4 )}\end{array}$ \\
\hline $\operatorname{ROA}_{t-I}$ (stand.) & & & $\begin{array}{c}-0.0529 * * * \\
(-\mathbf{6 . 0 2})\end{array}$ & $\begin{array}{l}-0.0516^{* * *} \\
(\mathbf{- 5 . 3 9 )}\end{array}$ \\
\hline StdRet (stand.) & & & $\begin{array}{l}-0.0155^{* *} \\
(\mathbf{- 2 . 4 8})\end{array}$ & ${ }^{-0.0164^{* *}}$ \\
\hline Log (Average Age) & & & & $\begin{array}{l}-0.3991^{* * *} \\
(\mathbf{- 5 . 4 3 )}\end{array}$ \\
\hline Log (Board Size) & & & & $\begin{array}{l}0.1325^{* * *} \\
(\mathbf{6 . 5 8})\end{array}$ \\
\hline Log (Connections) & & & & $\begin{array}{l}0.4143^{* * *} \\
(\mathbf{1 6 . 4 2 )}\end{array}$ \\
\hline
\end{tabular}




\begin{tabular}{lc|c|c|c} 
Chair CEO & & & & \multicolumn{2}{|c}{$0.0376^{* * *}$} \\
& Yes & Yes & Yes & Yes \\
Year FE & Yes & Yes & Yes & Yes \\
Industry FE & 34,583 & 34,583 & 34,583 & 34,583 \\
\hline$N$
\end{tabular}

Panel B: Annual Cross-Sectional Regressions

\begin{tabular}{|c|c|c|c|c|c|c|}
\hline \multirow[b]{2}{*}{ Year } & \multicolumn{3}{|c|}{ Log (Tenure) } & \multicolumn{3}{|c|}{$\log (\text { Tenure })^{2}$} \\
\hline & 2 & 3 & 4 & 2 & 3 & 4 \\
\hline \multirow[t]{2}{*}{1996} & -0.3097 & -0.1733 & -0.1976 & 0.0399 & -0.0064 & 0.0084 \\
\hline & $(-0.98)$ & $(-0.57)$ & $(-0.65)$ & $(0.47)$ & $(-0.08)$ & $(0.10)$ \\
\hline \multirow[t]{2}{*}{1997} & -0.0710 & -0.1894 & -0.1738 & -0.0054 & 0.0276 & 0.0287 \\
\hline & $(-0.23)$ & $(-0.66)$ & $(-0.60)$ & $(-0.06)$ & $(0.36)$ & $(0.36)$ \\
\hline \multirow[t]{2}{*}{1998} & 0.3218 & 0.2266 & 0.1380 & $-0.1224^{*}$ & -0.0891 & -0.0492 \\
\hline & $(1.35)$ & $(1.02)$ & $(0.62)$ & $(-1.84)$ & $(-1.43)$ & $(-0.77)$ \\
\hline \multirow[t]{2}{*}{1999} & 0.2431 & -0.0603 & -0.1411 & -0.0905 & -0.0050 & 0.0263 \\
\hline & $(0.95)$ & $(-0.26)$ & $(-0.61)$ & $(-1.29)$ & $(-0.08)$ & $(0.41)$ \\
\hline \multirow[t]{2}{*}{2000} & $0.5279 * *$ & $0.4178 * *$ & 0.3518 & $-0.1591 * *$ & $-0.1135^{*}$ & -0.0873 \\
\hline & $(2.20)$ & (1.85) & $(1.55)$ & $(-2.46)$ & $(-1.86)$ & $(-1.42)$ \\
\hline \multirow[t]{2}{*}{2001} & $0.6047 * * *$ & 0.3347 & 0.3085 & $-0.1759 * * *$ & $-0.1083 *$ & -0.0905 \\
\hline & (2.69) & $(1.62)$ & $(1.49)$ & $(-2.84)$ & $(-1.90)$ & $(-1.58)$ \\
\hline \multirow[t]{2}{*}{2002} & $0.5970^{* * *}$ & $0.3358^{*}$ & 0.2920 & $-0.1514 * * *$ & $-0.0947 *$ & -0.0778 \\
\hline & (3.04) & (1.86) & $(1.62)$ & $(-2.76)$ & $(-1.87)$ & $(-1.53)$ \\
\hline \multirow[t]{2}{*}{2003} & $0.6810^{* * *}$ & $0.3581 *$ & 0.2242 & $-0.1598 * * *$ & $-0.0998^{*}$ & -0.0482 \\
\hline & (3.25) & (1.90) & $(1.19)$ & $(-2.77)$ & $(-1.91)$ & $(-0.91)$ \\
\hline \multirow[t]{2}{*}{2004} & $0.5143 * * *$ & $0.4096 * *$ & 0.2783 & $-0.1608^{* * *}$ & $-0.1313 * * *$ & $-0.0806^{*}$ \\
\hline & (2.83) & $(2.37)$ & $(1.60)$ & $(-3.22)$ & $(-2.76)$ & $(-1.67)$ \\
\hline \multirow[t]{2}{*}{2005} & $0.7230^{* * *}$ & $0.5413 * * *$ & $0.4142 * *$ & $-0.2015 * * *$ & $-0.1681 * * *$ & $-0.1176^{* *}$ \\
\hline & (3.36) & $(2.67)$ & $(2.03)$ & $(-3.48)$ & $(-3.07)$ & $(-2.12)$ \\
\hline \multirow[t]{2}{*}{2006} & $0.7655^{* * *}$ & $0.7355^{* * *}$ & $0.5979 * * *$ & $-0.2281 * * *$ & $-0.2274 * * *$ & $-0.1779 * * *$ \\
\hline & (3.76) & (3.80) & $(3.07)$ & $(-4.19)$ & $(-4.38)$ & $(-3.39)$ \\
\hline \multirow[t]{2}{*}{2007} & $0.5472 * * *$ & $0.4501 * *$ & $0.3696 *$ & $-0.1627 * * *$ & $-0.1479 * * *$ & $-0.1083 * *$ \\
\hline & $(2.60)$ & $(2.26)$ & (1.85) & $(-2.91)$ & $(-2.78)$ & $(-2.02)$ \\
\hline \multirow[t]{2}{*}{2008} & $0.5976^{* * *}$ & $0.4669 * *$ & $0.3745^{*}$ & $-0.1657 * * *$ & $-0.1448 * * *$ & $-0.1001^{*}$ \\
\hline & $(2.65)$ & $(2.20)$ & $(1.76)$ & $(-2.78)$ & $(-2.59)$ & $(-1.77)$ \\
\hline \multirow[t]{2}{*}{2009} & $0.6358 * *$ & $0.4563 * *$ & 0.3255 & $-0.1471 * *$ & $-0.1205^{* *}$ & -0.0659 \\
\hline & $(2.54)$ & $(2.02)$ & $(1.42)$ & $(-2.28)$ & $(-2.07)$ & $(-1.11)$ \\
\hline \multirow[t]{2}{*}{2010} & $0.5184^{* *}$ & 0.3343 & 0.1125 & $-0.1418^{* *}$ & $-0.1094 *$ & -0.0343 \\
\hline & (1.98) & $(1.36)$ & $(0.46)$ & $(-2.13)$ & $(-1.75)$ & $(-0.55)$ \\
\hline \multirow[t]{2}{*}{2011} & $1.3888 * * *$ & $1.1230^{* * *}$ & $0.9823 * * *$ & $-0.3282 * * *$ & $-0.2798 * * *$ & $-0.2292 * * *$ \\
\hline & $(5.08)$ & $(4.40)$ & (3.82) & $(-4.81)$ & $(-4.39)$ & $(-3.56)$ \\
\hline \multirow[t]{2}{*}{2012} & $0.9143^{* * *}$ & $0.7846^{* * *}$ & $0.6836^{* * *}$ & $-0.2093 * * *$ & $-0.1974 * * *$ & $-0.1618^{* * *}$ \\
\hline & (3.53) & (3.28) & $(2.82)$ & $(-3.21)$ & $(-3.28)$ & $(-2.64)$ \\
\hline \multirow[t]{2}{*}{2013} & $1.1246^{* * *}$ & $1.1072 * * *$ & $0.9663 * * *$ & $-0.2550 * * *$ & $-0.2721 * * *$ & $-0.2210^{* * *}$ \\
\hline & (4.18) & $(4.40)$ & $(3.82)$ & $(-3.80)$ & $(-4.32)$ & $(-3.47)$ \\
\hline \multirow[t]{2}{*}{2014} & $1.2334 *$ & 0.6786 & 0.3594 & $-0.3340 *$ & -0.2048 & -0.0925 \\
\hline & $(1.70)$ & $(0.97)$ & $(0.51)$ & $(-1.90)$ & $(-1.20)$ & $(-0.54)$ \\
\hline
\end{tabular}




\begin{tabular}{lccc|ccc}
\multicolumn{1}{c}{2015} & 0.1956 & 0.1790 & -0.0079 & -0.0283 & -0.0295 & 0.0323 \\
& $(0.81)$ & $(0.80)$ & $(-0.03)$ & $(-0.46)$ & $(-0.52)$ & $(0.55)$ \\
\multicolumn{1}{c}{2016} & $2.1484^{* *}$ & 0.9977 & 0.5117 & $-0.5272 * *$ & -0.3012 & -0.1844 \\
& $(\mathbf{2 . 1 5 )}$ & $(1.11)$ & $(0.56)$ & $\mathbf{( - 2 . 2 5 )}$ & $(-1.43)$ & $(-0.86)$ \\
\hline & & & & & & \\
Industry FE & Yes & Yes & Yes & Yes & Yes & Yes \\
Firm Controls & No & Yes & Yes & No & Yes & Yes \\
Board Controls & No & No & Yes & No & No & Yes \\
\hline $\mathrm{N}$ & 34,583 & 34,583 & 34,583 & 34,583 & 34,583 & 34,583 \\
\hline
\end{tabular}

The table reports regression results of contemporaneous market-to-book on director, firm, and board characteristics. The regression specification is as follows:

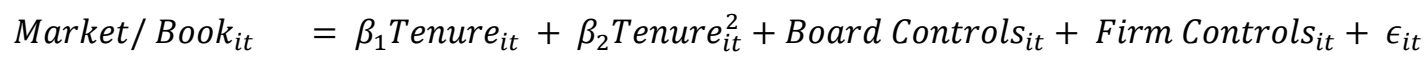

In all regression iterations the dependent variable is contemporaneous market-to-book ratio. Tenure is the average of the tenure of all independent directors sitting on the board. An individual director's tenure is calculated as the year of annual meeting minus the start year of directorship minus any breaks in the service of directorship. Firm Age (years) is the number of years since the firm is first listed in CRSP database. Sales are 12-month sales for a company. SegNum is the number of business segments. Intangibles are total intangible assets divided by lagged total assets. Leverage is long-term and short-term debt divided by lagged total assets. $R \& D$ is research and development expenditures from the prior four quarters divided by sales from the prior four quarters. ROA is operating income before depreciation over the prior four quarters divided by lagged total asset. StdRet is the standard deviation of daily stock returns during the prior calendar year. Average Age is the average age of board members. Board Size is the number of directors. Connections is the average number of boards the board members serve on (including the firm observation). Chair $C E O$ is an indicator variable that equals to one when the $\mathrm{CEO}$ also serves as board chair, zero otherwise. Stand denotes that for regression purposes a variable was normalized using the Blom function which transforms a variable to a normal distribution with a range between plus and minus three. In Panel $\mathrm{B}$ we chose to show only the coefficients on $\log$ (Tenure) and Log (Tenure $)^{2}$ with all other controls suppressed. In Panel B the tstatistic for the average coefficient is computed using the Fama and Macbeth methodology. Fama and French's 48 industry definitions are used for the industry fixed effects. The T-statistics are in parentheses and statistically significant terms are bolded. $* * *, * *,{ }^{*}$ denote significance at $1 \%, 5 \%$ and $10 \%$ level.

As a robustness check, we examine model (1) cross-sectionally for each year in our sample. The coefficients from the annual regressions, as well as average coefficients and Fama-Macbeth t-statistics are reported in Table 2 Panel B. We only show the coefficients and t-statistics for Tenure and Tenure Squared; but indicate for each regression whether industry, firm, and board controls are included. Similar to our panel regression results, we continue to observe a positive and significant coefficient for Tenure and negative and significant coefficient for the squared Tenure term for most years in our sample.

We recognize that our results might be affected by possible endogeneity of our board tenure constructs. As an attempt at addressing these endogeneity concerns, we estimate the statistical association between Tenure and firm value using next-period market-to-book as a dependent variable, while controlling for market-to-book ratios in the current year. The results (presented in Table 3) continue to confirm our prediction of a positive relationship between Tenure and firm value (positive and significant coefficient for Tenure), with the relationship deteriorating beyond a certain point (negative and significant coefficient for the squared term). The results in Table 3 suggest that our findings in Table 2 are robust to potential econometric problems induced by endogenous independent variables. Furthermore, it reveals that while board tenure effects are associated with contemporaneous market-to-book, the market does not appear to fully appreciate the importance of board tenure and the positive effect of tenure persists in the forward-looking measure of equity value. This finding strengthens our expectation that the positive effect of board tenure is also reflected in stock returns. 
TABLE 3

IMPACT OF BOARD TENURE ON THE NEXT YEAR FIRM MARKET VALUE

\begin{tabular}{|c|c|c|c|c|}
\hline & \multicolumn{4}{|c|}{ Dependent Variable $=$ Forward Market/ Book (stand.) } \\
\hline & 1 & 2 & 3 & 4 \\
\hline Log (Tenure) & $\begin{array}{l}0.0729 * * * \\
(10.94)\end{array}$ & $0.2459 * * *$ & $0.2031^{* * *}$ & $0.1731^{* * *}$ \\
\hline $\log (\text { Tenure })^{2}$ & & $\begin{array}{l}-0.0482 * * * \\
(\mathbf{- 5 . 8 5})\end{array}$ & $\begin{array}{l}-0.0416^{* * *} \\
(-5.04)\end{array}$ & $\begin{array}{l}-0.0348^{* * * *} \\
(-3.57)\end{array}$ \\
\hline Market/Book (stand.) & $\begin{array}{l}0.7941 * * * \\
\text { (219.14) }\end{array}$ & $\begin{array}{l}0.7933 * * * \\
(\mathbf{2 1 8 . 8 7 )}\end{array}$ & $\begin{array}{l}0.7844 * * * \\
(\mathbf{2 0 3 . 4 8 )}\end{array}$ & $\begin{array}{l}0.7818^{* * *} \\
(\mathbf{1 8 3 . 3 7 )}\end{array}$ \\
\hline Log (Firm Age) & & & ${ }^{0.0179 * * *}$ & $(\mathbf{2 . 3 6})^{0.0133^{* *}}$ \\
\hline Log (Sales) & & & ${ }^{0.0254 * * *}$ & ${ }^{0.0147 * * *}$ \\
\hline Log (SegNum) & & & ${ }^{-0.0257^{* *}}$ & $\begin{array}{l}-0.0224 * * \\
(-2.46)\end{array}$ \\
\hline Intangibles (stand.) & & & $\begin{array}{l}-0.0199 * * * \\
(-\mathbf{3 . 5 4})\end{array}$ & $\begin{array}{l}-0.0216^{* * * *} \\
(-\mathbf{3 . 5 0})\end{array}$ \\
\hline Leverage (stand.) & & & $(0.26)^{0.0010}$ & $(0.72)^{0.0032}$ \\
\hline R\&D (stand.) & & & $\begin{array}{l}0.0687^{* * *} \\
(\mathbf{1 0 . 0 8 )}\end{array}$ & $\begin{array}{l}0.0624^{* * *} \\
(\mathbf{8 . 3 4})\end{array}$ \\
\hline ROA $t$ (stand.) & & & ${ }^{-0.0219 * * *}$ & $\begin{array}{l}-0.0255^{* * *} \\
(-\mathbf{3 . 5 5})\end{array}$ \\
\hline ROAt-1 (stand.) & & & $\begin{array}{l}0.0485^{* * *} \\
(\mathbf{7 . 7 2})^{-}\end{array}$ & $\begin{array}{l}0.0516^{* * *} \\
(\mathbf{7 . 5 5 )}\end{array}$ \\
\hline StdRet (stand.) & & & $(-5.60)^{-0.0252}$ & $\begin{array}{l}-0.0223 * * * \\
(-4.54)\end{array}$ \\
\hline Log (Average Age) & & & & $(0.13)^{0.0066}$ \\
\hline Log (Board Size) & & & & $(\mathbf{2 . 0 4})^{0.0294 * *}$ \\
\hline Log (Connections) & & & & $(7.29)$ \\
\hline Chair CEO & & & & $(-0.86)^{-0.0064}$ \\
\hline Year FE & Yes & Yes & Yes & Yes \\
\hline Industry FE & Yes & Yes & Yes & Yes \\
\hline$N$ & 34,082 & 34,082 & 34,082 & 34,082 \\
\hline
\end{tabular}

The table reports regression results of forward market-to-book on director, firm, and board characteristics. The regression specification is as follows:

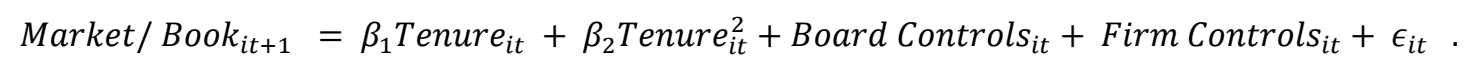

In all regression iterations the dependent variable is the next-year market-to-book ratio. In all regressions we also control for current year market-to-book. Tenure is the average of the tenure of all independent directors sitting on the board. An individual director's tenure is calculated as the year of annual meeting minus the start year of directorship minus any breaks in the service of directorship. Firm Age (years) is the number of years since the firm is first listed in CRSP database. Sales are 12-month sales for a company. SegNum is the number of business segments. Intangibles are total intangible assets divided by lagged total assets. Leverage is long-term and short-term debt divided by lagged total assets. $R \& D$ is research and development expenditures from the prior four quarters divided by sales from the prior four quarters. $R O A$ is operating income before depreciation over the prior four quarters divided by lagged total asset. StdRet is the standard deviation of daily stock returns during the prior calendar year. Average Age is the average age of board members. Board Size is the number of directors. Connections is the average number of boards the board members serve on (including the firm observation). Chair $C E O$ is an 
indicator variable that equals to one when the CEO also serves as board chair, zero otherwise Stand denotes that for regression purposes a variable was normalized using the Blom function which transforms a variable to a normal distribution with a range between plus and minus three. Industry fixed effect is at Fama French's 48 industries classification. The $\mathrm{T}$-statistics are in parentheses and statistically significant terms are bolded. $* * *, * * *$ denote significance at $1 \%, 5 \%$ and $10 \%$ level.

The results of our analysis of value relevance of board tenure for growth firms are presented in Table 4 (Panel A shows the results of panel regressions and Panel B - Fama-MacBeth style regressions). The results indicate that tenure is negatively related to firm value for high-growth firms: the coefficients on the interaction of all growth proxy dummies and the squared Tenure term are negative for all proxies and significant in most cases. In all four specifications, Tenure remains positively associated with firm value, while the squared Tenure term remains negative, which is consistent with our previous findings. Overall, the results in Table 4 provide evidence that confirms our prediction that longer Tenure is detrimental to the market value of high growth firms beyond a certain point. Our growth option analysis provides some evidence that the relationship between board tenure and firm value can be further refined by factoring in additional firm-specific attributes.

\section{TABLE 4}

\section{IMPACT OF GROWTH OPTIONS ON THE VALUE RELEVANCE OF BOARD TENURE: MARKET VALUATION EVIDENCE}

Panel A: Panel Regression

\begin{tabular}{|c|c|c|c|c|}
\hline & \multicolumn{4}{|c|}{ Dependent Variable $=$ Contemporaneous Market to Book (stand.) } \\
\hline & \multicolumn{4}{|c|}{ Growth Option Proxy $=$} \\
\hline & $R \& D$ & Sales Growth 1 & Sales Growth3 & Fluidity \\
\hline \multirow{2}{*}{ Growth $\times \log (\text { Tenure })^{2}$} & $-0.0205 * * *$ & $-0.0201 * * *$ & -0.0022 & $-0.0119 * *$ \\
\hline & $(-3.31)$ & $(-3.87)$ & $(-0.41)$ & $(-2.13)$ \\
\hline \multirow[t]{2}{*}{ Log (Tenure) } & $0.1424 * * *$ & $0.1306^{* * *}$ & $0.1470 * * *$ & $0.1354 * * *$ \\
\hline & (2.96) & (2.77) & (3.08) & (2.81) \\
\hline \multirow{2}{*}{$\log (\text { Tenure })^{2}$} & $-0.0393 * * *$ & $-0.0336 * * *$ & $-0.0447 * * *$ & $-0.0382 * * *$ \\
\hline & $(-3.01)$ & $(-2.59)$ & $(-3.42)$ & $(-2.91)$ \\
\hline \multirow[t]{2}{*}{ Growth Option Proxy } & $0.0749 * *$ & $0.4245 * * *$ & $0.2396 * * *$ & $0.0771 * * *$ \\
\hline & $(2.09)$ & (18.05) & (10.01) & (3.08) \\
\hline Firm Controls & Yes & Yes & Yes & Yes \\
\hline Board Controls & Yes & Yes & Yes & Yes \\
\hline Year FE & Yes & Yes & Yes & Yes \\
\hline Industry FE & Yes & Yes & Yes & Yes \\
\hline Observations & 34,583 & 34,583 & 34,583 & 34,583 \\
\hline
\end{tabular}

Panel B: Fama-MacBeth Regression

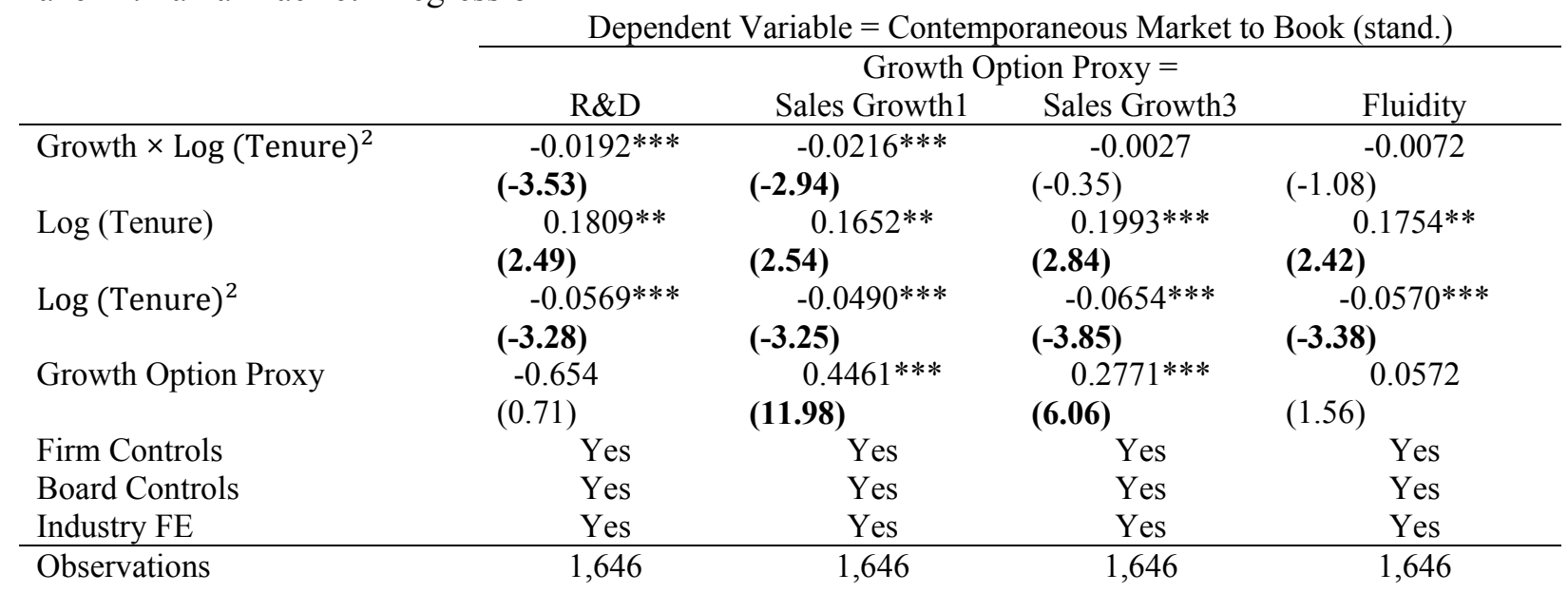


The table below reports regression results where the dependent variable is contemporaneous market-to-book ratio. In each column we report results of the following specification that includes one of our four proxies for firm growth:

$$
\begin{aligned}
{\text { Market } / \text { Book }_{i t}} & \\
& =\beta_{1} \text { Tenure }_{i t}+\beta_{2} \text { Tenure }_{i t}^{2}+\text { Tenure }_{i t}^{2} \times \text { Growth Proxy }+ \text { Growth Proxy Dummy } \\
& + \text { Board Controls }_{i t}+\text { Firm Controls }_{i t}+\epsilon_{i t}
\end{aligned}
$$

We use four proxies for firm growth: (i) $R \& D$, which is an indicator variable equal to one if the firm's ratio of research and development expenses to sales is over the 75th percentile value for all firms for that year. (ii) SalesGrowth1, which is an indicator variable equal to one if the firm's sales growth in the most recent four quarters over the previous four quarters is above the median value of other firms for the year. (iii) SalesGrowth3, which is an indicator variable equal to one if the firm's sales growth of the most recent four quarters over the corresponding period three years ago is above the median value of other firms for the year. (iv) Fluidity is an indicator variable equal to one if firm's Fluidity score is above the median value of other firms for the year. Fluidity is the fluidity score obtained from the online data (http://cwis.usc.edu/projects/industrydata/industryconcen.htm) provided by Hoberg and Phillips. All board and firm control variables are as defined in Table 2. In the interest of conciseness, we report only the results on the key independent variables. Panel A reports the results of panel regression. Industry fixed effect is at Fama French's 48 industries classification. The T-statistics are in parentheses and statistically significant terms are bolded. Panel B reports the results of Fama-MacBeth style regressions. Panel B reports average coefficients from 21 annual cross-sectional regressions. The averages are time-series means with t-statistics (in parentheses) corresponding to the standard error of the mean; statistically significant terms are bolded. $N$ denotes the average number of cross-sectional observations. ${ }^{* *}, * *, *$ denote significance at $1 \%, 5 \%$ and $10 \%$ level.

\section{Board Tenure and Stock Returns}

The analysis presented above suggests that increasing board tenure is positively related to firm value up to a certain point, after which board tenure becomes a drag on firm valuation. This relationship holds for both contemporaneous and forward-looking measure of market value. The latter finding, in particular, suggests that a similar relationship may hold for stock returns. If so, this would allow for a portfolio strategy that exploits the information content of board tenure. We investigate this further by studying the hypothetical portfolio returns investors could have generated by buying firms with certain board tenure attributes.

The first two columns in Table 5 present average abnormal monthly returns ( $X$ RET and $D G T W_{-} R E T$ ) for quintiles and deciles of portfolios formed based on Tenure. Both measures of abnormal returns are increasing monotonically to the middle of the Tenure range with the highest value at sixth decile: 0.41 percent monthly return for X_RET and 0.26 for DGTW_RET. In deciles seven through ten, both $X \_R E T$ and $D G T W \_R E T$ start to flatten out and decline. The magnitude of the spread return earned by investor who takes a long position in the highest quintile/ decile of stocks ranked on Tenure and a short position in the lowest groups range from 0.70 percent to 0.49 percent per month (statistically significant at the $1 \%$ level). However, it appears a more appealing strategy would be to go long on the firms in the middle groups of stock sorted on tenure, while shorting firms within the lowest Tenure group (monthly returns on this strategy would be up to 0.74 percent for $X_{-} R E T$ and 0.72 percent for $D G T W$ XRET).

Our additional measure of abnormal returns is the intercept ( $\left.F F \_R E T\right)$ of a four-factor model that includes three Fama-French factors and momentum, as specified in Model (4). The intercept from these regressions follows a pattern that is similar to that of $X_{-} R E T$ and DGTW_RET: the spread abnormal returns range from $0.51 \%$ for the quintiles of Tenure portfolios (Panel A) to $0.72 \%$ for the deciles (Panel B). 
TABLE 5

ABNORMAL STOCKS RETURNS TO PORTFOLIOS SORTED BY BOARD TENURE

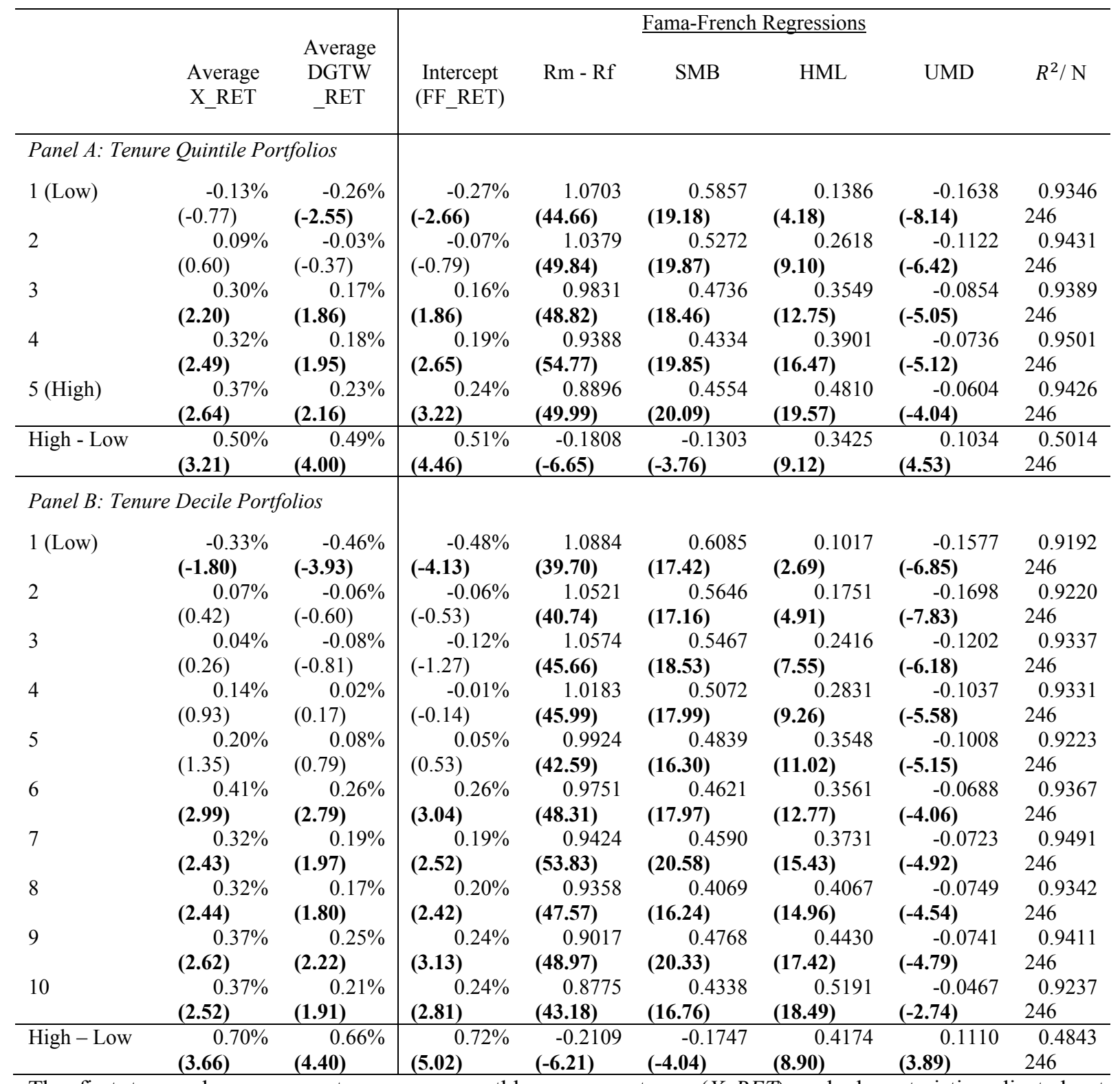

The first two columns presents average monthly excess returns $\left(X_{-} R E T\right)$ and characteristic adjusted returns (DGTW_RET) for quintiles and deciles of portfolios formed based on Tenure. $X \_R E T$ are monthly buy and hold security returns from CRSP in excess of the value-weighted market portfolio. $D G T W_{-} R E T$ are characteristicadjusted returns calculated as the monthly buy and hold security returns from CRSP minus the value-weighted average buy and hold return on securities with the same size (market capitalization, 3 groups), Book/Market ( 3 groups) and 11-month momentum (3 groups). The remaining columns show the results of Fama-French regressions for quintiles and deciles of portfolios formed based on Tenure. The regressions have the following specification:

$$
R p_{t}-R f_{t}=F F_{-} R E T+b \cdot\left[R m_{t}-R f_{t}\right]+s \cdot S M B_{t}+h \cdot H M L_{t}+u \cdot U M D_{t}+e_{t}
$$

Dependent variables are portfolio returns, $R p t$, in excess of the one-month Treasury bill rate, $R f t$, observed at the beginning of the month. The intercept denotes the risk adjusted return, $F F_{-} R E T$. Each month we form equalweighted portfolios of all sample firms based the length of directors' tenure (Tenure). The three Fama-French factors are zero investment portfolios representing the excess return of the market, $R m-R f$; the difference between a 
portfolio of "small" stocks and "big" stocks, $S M B$; and the difference between a portfolio of "high" book-tomarket stocks and "low" book-to-market stocks, $H M L$. The fourth factor, $U M D$, is the difference between a portfolio of stocks with high past one-year returns and a portfolio of stocks with low past one-year returns. The number of monthly cross-sectional regressions is denoted by $N$ and $t$-statistics are in parentheses; statistically significant terms are bolded.

Figure 4 plots $X \_R E T, D G T W_{-} R E T$ and $F F \_R E T$ for the deciles of portfolios formed on board tenure. For all three measures the pattern is similar to the inverted U-shape for market value observed in Figure 3. These results verify that the relationship observed between board tenure and firm value is also reflected in various measures of excess stock returns.

\section{EXCESS RETURNS ON FIRMS SORTED BY TENURE DECILES}

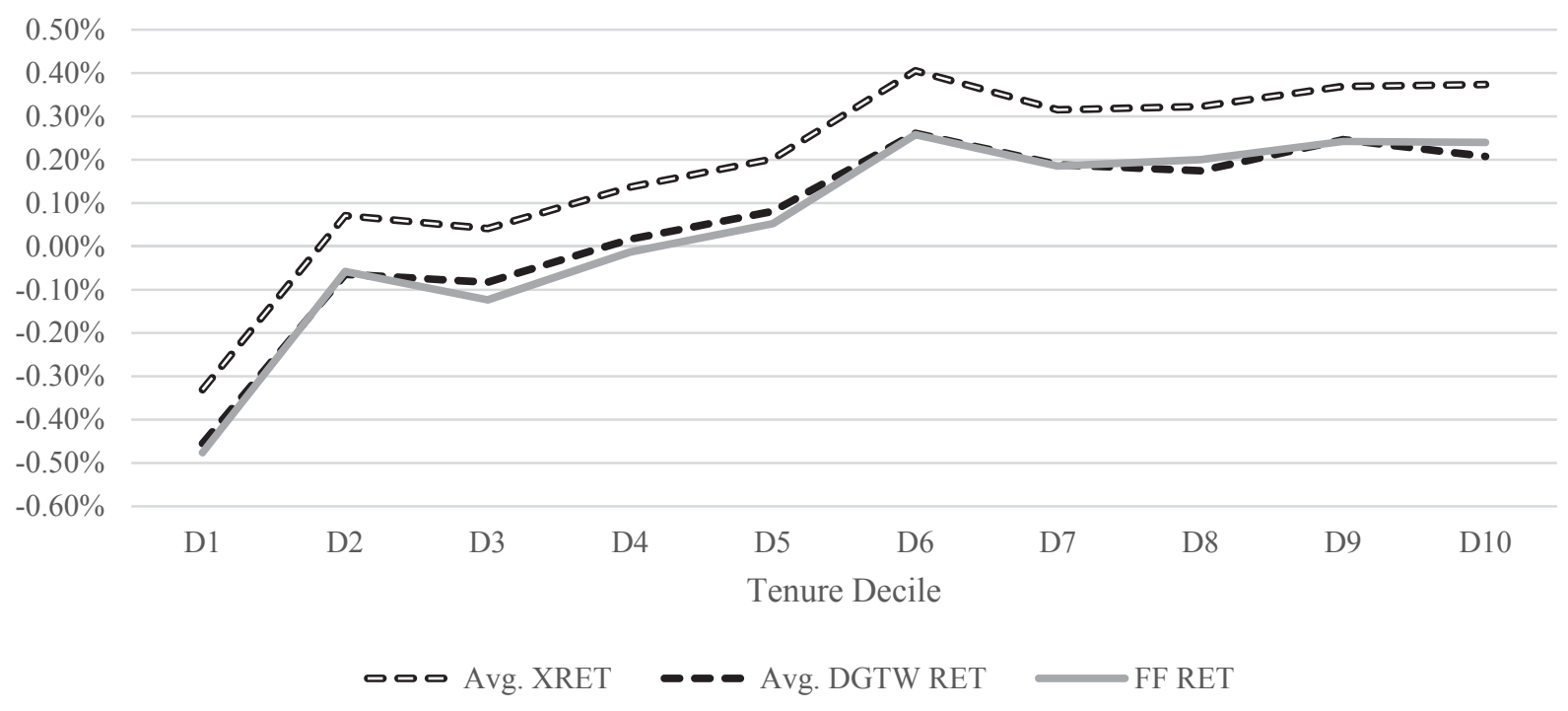

Next we test whether the relationship between stock returns and board tenure holds in a multivariate setting. Following Fama and MacBeth (1973), we regress characteristic-adjusted excess returns (DGTW_RET) on Tenure and the squared Tenure term, including firm, board and industry controls, as specified in Model (5). We use time-series means and t-statistics for statistical inference. As Table 6 reveals, the coefficient on Tenure is positive and significant across all specifications, verifying an overall positive relationship between Tenure and excess returns. For regression (1), we find that in a univariate regression board tenure is positively related to future returns and is significant, unlike our findings for market-to-book. 


\section{TABLE 6}

FAMA-MACBETH CROSS-SECTIONAL REGRESSIONS OF MONTHLY STOCK RETURNS

\begin{tabular}{|c|c|c|c|c|}
\hline & \multicolumn{4}{|c|}{ Dependent Variable $=$ DGTW_RET } \\
\hline & 1 & 2 & 3 & 4 \\
\hline Log (Tenure) & $\begin{array}{l}0.0030^{* * *} \\
(\mathbf{4 . 7 1 )}\end{array}$ & $\begin{array}{l}0.0077^{* * *} \\
(\mathbf{3 . 2 0})\end{array}$ & $\begin{array}{l}0.0071^{* * * *} \\
(\mathbf{2 . 8 2})\end{array}$ & ${ }_{(\mathbf{2 . 4 3})}^{0.0058^{* *}}$ \\
\hline $\log (\text { Tenure })^{2}$ & & $(-2.23)^{-0.0013^{* *}}$ & $(-2.21)$ & $(-1.61)^{-0.0010}$ \\
\hline Log (Firm Age) & & & $(-1.21)^{-0.0005}$ & $(-1.34)^{-0.0006}$ \\
\hline Log (SegNum) & & & $(0.29)^{0.0002}$ & $(0.38)^{0.0003}$ \\
\hline Intangibles (stand.) & & & $(-1.29)^{-0.0006}$ & $(-0.69)^{-0.0004}$ \\
\hline Leverage (stand.) & & & $(-0.75)^{-0.0003}$ & $(-0.62)^{-0.0003}$ \\
\hline $\mathrm{R} \& \mathrm{D}$ (stand.) & & & $(0.48)^{0.0004}$ & $(0.36)^{0.0003}$ \\
\hline ROA (stand.) & & & $\begin{array}{l}0.0019^{* * *} \\
(\mathbf{2 . 7 3})\end{array}$ & ${ }^{0.0026^{* * *}}$ \\
\hline $\mathrm{ROA}_{t-1}$ (stand.) & & & $(-0.59)^{0.0004}$ & $(0.05)^{0.0000}$ \\
\hline StdRet (stand.) & & & $(-1.07)^{-0.0008}$ & $(-0.61)^{-0.0005}$ \\
\hline Log (Average Age) & & & & $(-1.58)^{-0.0063}$ \\
\hline Log (Board Size) & & & & $(1.00)^{0.0012}$ \\
\hline Log (Connections) & & & & ${ }^{0.0054 * * *}$ \\
\hline Chair CEO & & & & $(-0.74)^{-0.0004}$ \\
\hline Year FE & Yes & Yes & Yes & Yes \\
\hline Industry FE & Yes & Yes & Yes & Yes \\
\hline$N$ & 1,620 & 1,620 & 1,620 & 1,620 \\
\hline
\end{tabular}

The table reports regression results estimating variations of the following regression:

$$
D G T W_{-} R E T_{i t+1}=\beta_{1} \text { Tenure }_{i t}+\beta_{2} \text { Tenure }_{i t}^{2}+\text { Board Controls }_{i t}+\text { Firm Controls }_{i t}+\epsilon_{i t}
$$

In all regression iterations the dependent variable is the one-month ahead excess stock return - DGTW_RET (characteristic adjusted returns calculated as the monthly buy and hold security returns from CRSP minus the valueweighted average buy and hold return on securities with the same size (market capitalization, 3 groups), Book/Market (3 groups) and 11-month momentum (3 groups)). Tenure is the average of the tenure of independent directors sitting on the board. An individual director's tenure is calculated as the year of annual meeting minus the start year of directorship minus any breaks in the service of directorship. Firm Age (years) is the number of years since the firm is first listed in CRSP database. SegNum is the number of business segments. Intangibles are total intangible assets divided by lagged total assets. Leverage is long-term and short-term debt divided by lagged total assets. $R \& D$ is research and development expenditures from the prior four quarters divided by sales from the prior four quarters. $R O A$ is operating income before depreciation over the prior four quarters divided by lagged total asset. StdRet is the standard deviation of daily stock returns during the prior calendar year. Average Age is the average age of board members. Board Size is the number of directors. Connections is the average number of boards the board members serve on (including the firm observation). Chair CEO is an indicator variable that equals to one when the CEO also serves as board chair, zero otherwise. DGTW_RET is winsorized at $99 \%$ and $1 \%$. The table reports average coefficients from 251 monthly cross-sectional regressions. The averages are time-series means with t- 
statistics (in parentheses) computed using the standard error of the mean; statistically significant terms are bolded. $N$ denotes the average number of cross-sectional observations. Industry fixed effect is at Fama French's 48 industries classification. $* * * * * *$ denote significance at $1 \%, 5 \%$ and $10 \%$ level.

The relationship between board tenure and future returns can be strengthened by including a quadratic tenure term. In regression (2) we include a squared board tenure term and find the coefficient on board tenure is now two times the size as the comparable coefficient in regression (1). Moreover, the squared term in regression (2) is negative and significant at the 5\% level. Once we control for firm and board effects, the board tenure coefficients and significance are only modestly reduced, demonstrating the strength of the result. This confirms our prediction that board tenure is a positive for firms up to a certain point; however, after that further benefits do not arise for shareholders.

We now revisit our predictions that for high-growth firms the deterioration of firm value will show at the earlier stages of board tenure. We investigate whether the evidence from Table 4 suggesting that long board tenure is especially damaging to the market value of high-growth companies also holds for stock returns. Table 7 repeats the analysis performed in Table 4, adding one more proxy for growth - Marketto-Book. Specifically, we regress our measure of excess stock returns (DGTW_RET) on the interaction of the squared Tenure term and the growth dummy, keeping all other controls used in model (4). The results in Table 7 are weaker but consistent with the evidence uncovered previously in Table 4: the coefficient on the interaction variable is negative and statistically significant in one specification, while the rest of proxies seem to be statistically insignificant. The Tenure term is consistently positive and significant, while the squared term remains negative and significant.

\section{TABLE 7 \\ IMPACT GROWTH OPTIONS ON THE VALUE RELEVANCE OF BOARD TENURE: STOCK RETURN EVIDENCE}

\begin{tabular}{lccccc} 
& \multicolumn{5}{c}{ Dependent Variable= DGTW_RET } \\
\cline { 2 - 5 } & \multicolumn{4}{c}{ Growth Option Proxy = } \\
& M/B & R\&D & Sales Growth1 & Sales Growth3 & Fluidity \\
\hline Growth $\times$ Log (Tenure) $)^{2}$ & $-0.0004^{*}$ & -0.0002 & 0.0002 & 0.0004 & 0.0001 \\
& $\mathbf{( - 1 . 7 0 )}$ & $(-0.49)$ & $(0.67)$ & $(1.46)$ & $(0.08)$ \\
Log (Tenure) & $0.0058^{* *}$ & $0.0056^{* *}$ & $0.0060^{* *}$ & $0.0055^{* *}$ & $0.0059^{* *}$ \\
& $\mathbf{( 2 . 4 3 )}$ & $\mathbf{( 2 . 3 4 )}$ & $\mathbf{( 2 . 4 9 )}$ & $\mathbf{( 2 . 3 0 )}$ & $\mathbf{( 2 . 4 4 )}$ \\
Log (Tenure) & -0.0008 & -0.0009 & $-0.0011^{*}$ & $-0.0011^{*}$ & -0.0010 \\
& $(-1.25)$ & $\mathbf{( - 1 . 4 6 )}$ & $\mathbf{( - 1 . 7 5 )}$ & $\mathbf{( - 1 . 7 5 )}$ & $(-1.52)$ \\
Growth Option Proxy & -0.0007 & 0.0014 & -0.0016 & $-0.0024^{*}$ & 0.0013 \\
& $(-0.44)$ & $(0.47)$ & $(-1.15)$ & $\mathbf{( - 1 . 7 6 )}$ & $(0.88)$ \\
Firm Controls & Yes & Yes & Yes & Yes & Yes \\
Board Controls & Yes & Yes & Yes & Yes & Yes \\
\hline$N$ & 1,620 & 1,620 & 1,620 & 1,620 & 1,620 \\
\hline
\end{tabular}

The table below reports regression results where the dependent variable, $D G T W_{-} R E T$, is one month ahead characteristic adjusted returns calculated as the monthly buy and hold security returns from CRSP minus the valueweighted average buy and hold return on securities with the same size (market capitalization, 3 groups), Book/Market (3 groups) and 11-month momentum (3 groups). In each column we report results of the following specification that includes one of our five proxies for firm growth:

$$
\begin{aligned}
\text { DGTW_RET }_{i t+1} & =\beta_{1} \text { Tenure }_{i t}+\beta_{2} \text { Tenure }_{i t}^{2}+\text { Tenur }_{i t}^{2} \times \text { Growth Proxy }_{+} \text {Growth Proxy Dummy } \\
& + \text { Board Controls }_{i t}+\text { Firm Controls }_{i t}+\epsilon_{i t}
\end{aligned}
$$

We use five proxies for firm growth: (i) $M / B$ is an indicator variable equal to one if firm's market-to-book ratio is above the median value of other firms for the year. (ii) $R \& D$, which is an indicator variable equal to one if the firm's 
ratio of research and development expenses to sales is over the 75th percentile value for all firms for that year. (iii) SalesGrowth1, which is an indicator variable equal to one if the firm's sales growth in the most recent four quarters over the previous four quarters is above the median value of other firms for the year. (iv) SalesGrowth3, which is an indicator variable equal to one if the firm's sales growth of the most recent four quarters over the corresponding period three years ago is above the median value of other firms for the year. (v) Fluidity is an indicator variable equal to one if firm's Fluidity score is above the median value of other firms for the year. Fluidity is the fluidity score obtained from the online data (http://cwis.usc.edu/projects/industrydata/industryconcen.htm) provided by Hoberg and Phillips. All other control variables are as defined in Table 6. In the interest of conciseness, we report only the results on the key independent variables. DGTW_RET is winsorized at $99 \%$ and $1 \%$. The table reports average coefficients from 251 monthly cross-sectional regressions. The averages are time-series means with tstatistics (in parentheses) corresponding to the standard error of the mean; statistically significant terms are bolded. $N$ denotes the average number of cross-sectional observations. Industry fixed effect is at Fama French's 48 industries classification. $* * *, * *, *$ denote significance at $1 \%, 5 \%$ and $10 \%$ level.

\section{ROBUSTNESS TESTS}

Our research is not without inherent limitations. This section presents the results of additional tests to check the robustness of the main results. Specifically, we consider whether our results are driven by: 1) our sample selection, 2) our design of board tenure measure, 3) behavior of executive board members, 4) our selection of linear model to capture nonlinear relationship between firm value and board tenure, and 5) adverse selection of long-tenured board members. Additionally, in order to align our monthly return tests with the tests that use book-to-market as a dependent variable, we perform tests of the relationship between board tenure and stock returns by using annual stock returns as our dependent variable.

\section{Sample Selection}

Our results might be driven by the sample selection. First, we have fewer observations in the early years of our sample. Additionally, it is possible that the database started counting the length of tenure from the point of time that a director is added to the database. This would bias tenure in the early years of our sample to be shorter than it actually was. In order to address this concern, we separate our sample into two groups: a group of observations for the period of 1996-2003 and a group of observations for the period of 2004-2014. We test whether the relationship between board tenure and firm value and monthly returns holds for the two groups: Panel A of Table 8 reports the regression results. For both sub-periods, we find results that are consistent with our main findings. In particular, board tenure is positively related to firm value up to a certain point, after point the positive relationship reverses. This reversal is reflected in the negative coefficient of the squared Tenure term. 
TABLE 8

ROBUSTNESS TESTS: MARKET-TO-BOOK EVIDENCE

Panel A: Sample Selection.

\begin{tabular}{|c|c|c|c|c|}
\hline & 1996-2003 period & 2004-2014 period & Large-Cap & Small-Cap \\
\hline Log (Tenure) & 0.1003 & $0.4967 * * *$ & $0.2262 * * *$ & $0.3345 * * *$ \\
\hline & $(1.21)$ & (5.89) & (3.69) & (4.61) \\
\hline $\log (\text { Tenure })^{2}$ & $-0.0362 *$ & -0.1263 & $-0.0489 * * *$ & -0.1010 \\
\hline & $(-2.04)$ & $(-6.63)$ & $(-2.96)$ & $(-5.20)$ \\
\hline Year FE & Yes & Yes & Yes & Yes \\
\hline Industry FE & Yes & Yes & Yes & Yes \\
\hline$N$ & 8,024 & 23,226 & 16,296 & 14,957 \\
\hline
\end{tabular}

Panel B1: Design of Board Tenure Measure.

\begin{tabular}{lc|c|c|}
\hline & Median Tenure & High Std Tenure & Low Std Tenure \\
\hline Log (Tenure) & $0.1048^{* * *}$ & 0.2934 & 0.1215 \\
& $\mathbf{( 3 . 2 0 )}$ & $(1.42)$ & $(1.56)$ \\
Log $($ Tenure) & $-0.0270^{* * *}$ & $-0.0901^{*}$ & -0.0072 \\
& $\mathbf{( - 2 . 8 1 )}$ & $\mathbf{( - 2 . 0 0 )}$ & $(-0.29)$ \\
Year FE & Yes & Yes & Yes \\
Industry FE & Yes & Yes & Yes \\
\hline$N$ & 31,253 & 16,044 & 15,209 \\
\hline
\end{tabular}

Panel B2: Design of Board Tenure Measure.

\begin{tabular}{lc|c|}
\hline & Excluding D1 & Excluding D1-D2 \\
\hline Log (Tenure) & $0.4199 * * *$ & 0.2527 \\
& $\mathbf{( 3 . 8 3 )}$ & $\mathbf{( 1 . 6 1 )}$ \\
Log (Tenure) $)^{2}$ & $-0.1088 * * *$ & $-0.0740 * *$ \\
Year FE & $\mathbf{( - 4 . 1 5 )}$ & $\mathbf{( - 2 . 0 8 )}$ \\
Industry FE & Yes & Yes \\
\hline$N$ & Yes & Yes \\
\hline
\end{tabular}

Panel C: Use of Linear Model.

\begin{tabular}{|lc|c|}
\hline & $\begin{array}{c}\text { High Board } \\
\text { Tenure }\end{array}$ & $\begin{array}{c}\text { Low Board } \\
\text { Tenure }\end{array}$ \\
\hline Log (Tenure) & $-0.2059 * * *$ & $0.1290 * * *$ \\
& $\mathbf{( - 3 . 7 7 )}$ & $\mathbf{( 6 . 8 8 )}$ \\
Year FE & Yes & Yes \\
Industry FE & Yes & Yes \\
\hline$N$ & 7,842 & 23,411 \\
\hline
\end{tabular}

The relationship between board tenure and firm value may also change with firm size, consistent with the well-documented size anomaly (e.g., Fama and French $(1993,2014)$ ). To ensure that the paper's results are not driven by small-cap stocks, we re-perform our tests on the sub-samples of large-cap and small-cap stocks (we define large-cap companies as companies with market capitalization larger than the median market capitalization for the full sample in each year). The results in Panel A of Table 8 show that our findings hold both for large-cap and small-cap stocks: the board tenure has an inverted U-shape relationship with firm value for both sub-samples.

\section{Our Design Of Board Tenure Measure}

Another concern is that our main explanatory variable might be misspecified. Bonini et al. (2015) argue that using the average to capture the effect of long board tenure of the directors might be 
confounding the effect of a single long tenure, as it gets diluted by the tenure of the other board members with short or average tenures. To ensure that the paper's results are not driven by our choice of the main explanatory variable, we perform several additional robustness checks.

First, we replace the average board tenure with the median board tenure in our tests. Panel B1 of Table 8 presents the results of our baseline regression, using median as our main explanatory variable (Med Tenure). The coefficient on Med Tenure is positive and significant at the $1 \%$ level, while the coefficient on the squared term is negative and significant. In unreported results we also find that using median board tenure results also shows that the negative effect of the squared term is especially pronounced for high-growth firms. The results show that our findings are robust to using median as an alternative main explanatory variable.

Second, in order to further address the criticism that average board tenure might be a noisy measure, we examine whether our results are robust to different levels of standard deviation of board tenure. We separate our sample based on the median value of standard deviation of board tenure and re-run our baseline regression for the two sub-samples. Panel B1 shows the results for firms with high and low standard deviation of board tenure. Tenure and Tenure Squared terms retain their signs consistent with the main findings for both companies with high and low standard deviations of board tenure.

Finally, we test the effect of long board tenure on firm performance by using the proportion of longserving directors as a dependent variable. For each company, we calculate the number of directors with tenure greater than 15 years ("long-serving directors") and divide it by the total number of directors on the board in that year. We re-run regression (1) replacing average board tenure terms with the percentage of long-serving directors. The resulting coefficient on the dependent variable of interest is negative and significant at the $1 \%$ level, which supports our earlier conclusion that extreme terms of board tenure are detrimental to the firm values.

Our main results might also be driven by companies with extremely low board tenure. As can be seen in Figure 3, companies that belong to the first decile of the average board tenure have significantly lower market-to-book than the ones in deciles two or three. In order to address the criticism that our results might be driven by these outliers, we re-run our main results excluding firms that fall into decile one of average board tenure. The first column of Panel B2 shows that our results still hold if we restrict our test sample in this way: Tenure and Tenure Squared terms retain their signs and remain statistically significant at the $1 \%$ level. We further test the sensitivity of our results to the presence of low boardtenure companies in our sample by excluding firms both in decile one and two from our sample: the results are presented in column two of Panel B2. Even though the statistical significance of both Tenure and Tenure Squared terms weakens, the direction of the relationship between them and firm value remains unchanged.

\section{Use of Linear Model}

Standard linear models might be inappropriate to capture the relationship between firm value and a corporate governance construct due to potential nonlinearities between corporate governance measures and other variables. In order to address this concern, we perform an additional test to confirm that the reversal in the relationship between board tenure and firm value is correctly captured by the squared Tenure term.

We partition our sample into two groups. Each year, we create a high board tenure group of firms, and a corresponding low board tenure group. High board tenure firms are the ones that have average board tenure that exceeds the $75^{\text {th }}$ percentile of board tenure for that year; low board tenure firms are the rest of the firms in our sample. We then estimate Model (1) as a panel regression, and also in a crosssectional form, for each group of firms. We modify Model (1) by excluding the squared board tenure term because we would like to capture the point where the linear relationship between board tenure and firm value changes by creating the two groups of firms. Panel $\mathrm{C}$ of Table 8 presents the results of our test. We find that for our low board tenure sample board tenure is positively and significantly related to firm value. However, for our high board tenure sample, board tenure is negatively and significantly related to firm 
value. These results confirm our findings that board tenure and firm value are positively related, with the relationship reversing at longer terms of board tenure.

\section{Adverse Selection of Long-Tenured Board Members}

It may be argued that long-tenured board members remain on their boards because they are not offered better board memberships on other firms, and therefore cannot upgrade their board memberships into more prestigious boards (similar to the lemon argument by Akerlof (1970)). To assess whether this is the case, we identify all cases in our universe where a board member has added another board membership during the year. We then compare the new board membership to an average of the prior board memberships along several dimensions.

In unreported results, we find that the new firm that is added is typically smaller in terms of market value than the average firm in which the board member had membership in the prior year. It also is less profitable in terms of ROE, net income scaled by book value of equity, and has a lower B/M (book to market value of equity) ratio. We find a similar pattern when a board membership is dropped. The dropped firm is typically smaller and has lower ROE and B/M ratio than the remaining firms in which the board member retains membership.

We also examine the average tenure of board members who added one more board membership, and compare it to the average tenure of all other board members in the same firms. We find that the person who added a board membership had a board tenure that was shorter than the average of other members by just 0.3 years. Thus, our data does not support the conjecture that inferior board members remain on the board because they are not offered better opportunities.

\section{Board Tenure and Annual Stock Returns}

Our tests of board tenure and monthly stock returns are consistent with the prevailing asset pricing methodology. However, it can be argued that because board tenure variable is measured annually, next year annual stock returns might be a more appropriate dependent variable for the tests. To address this, we re-run our tests of stock returns and board tenure using excess annual stock returns as a dependent variable. Table 9 presents the results for all four specifications. Tenure term remains positive and significant, as we add firm and board controls, while Tenure Squared is consistently negative and significant in most specifications. These results confirm our prior findings regarding the relationship between board tenure and stock returns.

TABLE 9

ROBUSTNESS TESTS: ANNUAL STOCK RETURNS EVIDENCE

\begin{tabular}{|c|c|c|c|c|}
\hline & \multicolumn{4}{|c|}{ Dependent Variable $=$ DGTW_RET $_{\mathrm{it}+1}$} \\
\hline & 1 & 2 & 3 & 4 \\
\hline Log (Tenure) & $0.0300 * * *$ & $0.1108 * * *$ & $0.0964 * * *$ & $0.0800 * *$ \\
\hline & $(2.92)$ & (3.40) & (3.02) & $(2.60)$ \\
\hline $\log (\text { Tenure })^{2}$ & & $(-2.77)^{-0.0211^{* * *}}$ & $-0.0180 * *$ & $(-1.54)^{-0.0102}$ \\
\hline Firm Controls & No & No & Yes & Yes \\
\hline Board Controls & No & No & No & Yes \\
\hline Year FE & Yes & Yes & Yes & Yes \\
\hline Industry FE & Yes & Yes & Yes & Yes \\
\hline$N$ & 1,620 & 1,620 & 1,620 & 1,620 \\
\hline
\end{tabular}

The table reports regression results estimating variations of the following regression:

$$
D_{G T W} R E T_{i t+1}=\beta_{1} \text { Tenure }_{i t}+\beta_{2} \text { Tenure }_{i t}^{2}+\text { Board Controls }_{i t}+\text { Firm Controls } \text { Cit }_{i t}+\epsilon_{i t} .
$$


In all regression iterations the dependent variable is the one-year ahead excess stock return - DGTW_RET (characteristic adjusted returns calculated as the annual buy and hold security returns from CRSP minus the valueweighted average buy and hold return on securities with the same size (market capitalization, 3 groups), Book/Market (3 groups) and 11-month momentum (3 groups)). All independent variables are as defined in Table 6. In the interest of conciseness, we report only the results on the key independent variables. $D G T W \_R E T$ is winsorized at $99 \%$ and $1 \%$. The table reports average coefficients from 21 annual cross-sectional regressions. The averages are time-series means with t-statistics (in parentheses) corresponding to the standard error of the mean; statistically significant terms are bolded. $N$ denotes the average number of cross-sectional observations. Industry fixed effect is at Fama French's 48 industries classification. $* * *, * * *$ denote significance at $1 \%, 5 \%$ and $10 \%$ level.

\section{CONCLUSIONS}

Understanding the relationship between average board tenure and firm value is of fundamental importance to practitioners, academics and regulators. Calls of institutional and activist investors to "refresh the boards" and limit director tenure are shaping the regulatory environment. However, these actions are not supported by a consistent set of results in the corporate governance literature.

This paper studies the value relevance of board tenure using the largest sample of firms compared to previous studies in the literature. We find considerable support for the notion that longer board tenure is positively related to future stock returns, as well as contemporaneous and future firm value. The market rewards firms with long-serving boards with a 'stability' premium. However, over time, the effectiveness of two primary board functions - monitoring and advising management - deteriorates. Tenure has a direct negative effect on the boards' ability to keep up with the firm growth and a moderating effect on the board's incentive to monitor managers. Effectiveness of board members peaks at average tenure of about nine years, at which point board tenure begins to become a drag on the company valuation relative to the nine-year tenure. This reduction in effectiveness is especially pronounced for high-growth firms for which up-to-date knowledge of company operations is especially important for the company's success.

We add to the existing literature in a number of ways. First, our findings are less prone to the biases that characterize prior studies in the area: our large sample of firms across 20 years and various industries addresses some of the small sample issues of prior studies. Second, we use forward-looking measures of firm value to test the value-relevance of board tenure in an attempt to mitigate the endogeneity problem. Third, we examine the effect of board tenure on firm returns, which allows us to suggest a viable portfolio strategy based on the length of board tenure. Finally, we provide some evidence regarding the effect of tenure on high growth firms that partially explains the nonlinear relationship between board tenure and firm value. 


\section{REFERENCES}

Akerlof, G. A. (1970). The Market for 'lemons': quality uncertainty and the market mechanism. Quarterly Journal of Economics, 84(3), 488-500.

Baker, M., \& P. Gompers. (2003). The determinants of board structure at the initial public offering. Journal of Law and Economics, 46, 569-598.

Beasley, M. S. (1996). An empirical analysis of the relation between the board of director composition and financial statement fraud. The Accounting Review, 71(4), 443-465.

Berberich, G., \& Niu, F. (2011). Director business, director tenure and the likelihood of encountering corporate governance problem. Working paper, Wilfrid Laurier University.

Bhagat, S., \& Black, B. (2001). The non-correlation between board independence and long term firm performance. Journal of Corporation Law, 27, 231-274.

Bonini, S., Deng, J., Ferrari, M., \& John, K.. (2015). 'Til death do us part: the long tenured directors' puzzle. Working paper, Stevens Institute of Technology, New York University, University of Modena.

Boone, J., Khurana, I., \& Raman, K. (2008). Audit firm tenure and the equity risk premium. Journal of Accounting, Auditing \& Finance, 23(1), 115-140.

Brav, A., Lehavy, R., \& Michaely, R. (2005). Using expectations to test asset pricing models. Financial Management, 34(3), 31-64.

Carhart, M. (1997). On Persistence in Mutual Fund Performance. Journal of Finance, 52, 56-82.

Chevalier, J., \& Ellison, G. (1999). Career concerns of mutual fund managers. Quarterly Journal of Economics, 114(2), 389-432.

Coles, J., D. Naveen, and L. Naveen. (2015). Board Groupthink. Working paper, University of Utah, Drexel University, and Temple University.

Daniel, K., Grinblatt, M., Titman, S., \& Wermers, R. (1997). Measuring Mutual Fund Performance with Characteristic-Based Benchmarks. Journal of Finance, 52(3), 1035-1058.

Denis, D., \& Sarin, A. (1999). Ownership and board structures in publicly traded corporations. Journal of Financial Economics 52, 187-223.

Donoher, W. J., \& Reed, R. (2007). Employment capital, board control, and the problem of misleading disclosures. Journal of Managerial Issues, 19(3), 362-378.

Dou, Y., Sahgal, S., \& Zhang, E. J. (2015). Should independent directors have term limits? The role of experience in corporate governance. Financial Management, 44(3), 583-621.

Fama, E. (1980). Agency problems and the theory of the firm. Journal of Political Economy, 88, 288-307.

Fama, E. F., \& French, K. R. (1993). Common risk factors in the returns on stocks and bonds. Journal of Financial Economics, 33, 3-56.

Fama, E. F., \& French, K. R. (2015). A five-factor asset pricing model. Journal of Financial Economics, $116(1), 1-22$.

Fama, E. F., \& MacBeth, J. (1973). Risk, return, and equilibrium: empirical tests. Journal of Political Economy, 81, 607-636.

Fracassi, C., Petry, S., \& Tate, G. A. (2015). Does rating analyst subjectivity affect corporate debt pricing? Journal of Financial Economics, 120(3), 514-538.

Ghosh, A. (2006). Electoral cycles in crime in a developing country: evidence from the Indian States. Working paper, Mathematical Policy Research, Inc.

Goyal, V.K., \& Park, C.W. (2002). Board leadership structure and CEO turnover. Journal of Corporate Finance, 8, 49-66.

Hamouda, F., \& Arab, M. B. (2013). Board of directors and insider trading with share repurchase programs. Journal of Management \& Governance, 17(2), 405-418.

Hermalin, B., \& M. Weisbach. (1988). The determinants of board composition. Rand Journal of Economics, 19, 589-606. 
Hermalin, B., \& Weisbach, M. (1991). The effect of board composition and direct incentives on firm performance. Financial Management, 20, 101-112.

Hermalin, B.E., \& Weisbach, M.S., (1998). Endogenously chosen boards of directors and their monitoring of the CEO. American Economic Review, 88, 96-118.

Hillman, A.J., \& Dalziel, T. (2003). Boards of directors and firm performance: integrating agency and resource dependence perspectives. Academy of Management Review, 28(3), 383-396.

Hoberg, G., Phillips, G. M., \& Prabhala, N. (2014). Product market threats, payouts, and financial flexibility. Journal of Finance, 69(1), 293-324.

Howton, S. W. (2006). Effect of governance characteristics on the state of the firm after an initial public offering. Financial Review, 41(3), 419-433.

Huang, S., \& Hilary G. (2018). Zombie Board: Board Tenure and Firm Performance. Journal of Accounting Research, 2018.

Klein, A. (1998). Firm performance and board committee structure. Journal of Law and Economics, 41, 137-165.

Larcker, D. F., So, E. C., \& Wang, C. Y. (2013). Boardroom centrality and firm performance. Journal of Accounting \& Economics, 55(2-3), 225-250.

Li, S., \& Ou-Yang, H. (2010). Explicit incentives, implicit incentives, and performance: evidence from academic tenure. Working paper, Wilfrid Laurier University and Cheung Kong Graduate School of Business.

McClelland, P., Barker, V., \& Oh, W. (2012). CEO career horizon and tenure: future performance implications under different contingencies. Journal of Business Research, 65(9), 1387-1393.

McDonald, M., \& Westpal, J. (2003). Getting by with the advice of their friends: CEOs' advice networks and firms' strategic responses to poor performance. Administrative Science Quarterly, 48, 1-32.

Miller, D. (1991). Stale in the saddle: CEO tenure and the match between organization and environment. Management Science, 37, 34-52.

Muller-Kahle, M. I., \& Lewellyn, K. B. (2011). Did board configuration matter? The case of US subprime lenders. Corporate Governance: An International Review, 19(5), 405-417.

Pfeffer, J., \& Salancik, G. (1978). The external control of organizations: a resource-dependence perspective. New York: Harper \& Row.

Porter, G., \& Trifts, J. (2012). The best mutual fund managers: testing the impact of experience using a survivorship bias free dataset. Journal of Applied Finance, 22(1), 105-117.

Rajgopal, S., \& Shevlin, T. (2002). Empirical evidence on the relation between stock option compensation and risk taking. Journal of Accounting and Economics 33, 145-171.

Rutherford, M. A., \& Buchholtz, A. K. (2007). Investigating the relationship between board characteristics and board information. Corporate Governance: An International Review, 15(4), 576-584.

Sharma, V. (2011). Independent directors and the propensity to pay dividends. Journal of Corporate Finance, 17(4), 1001-1015.

Schnake, M. E., Fredenberger, W. B., \& Williams, R. J. (2005). The influence of board characteristics on the frequency of 10-k investigations of firms in the financial services sector. Journal of Business Strategies, 22(2), 101-117.

Vafeas, N. (2003). Length of board tenure and outside director independence. Journal of Business Finance \& Accounting, 30(7/8), 1043-1064.

Vekshin, A. (2015). CalPERS pushes boards to clear room for the young and ethnic. Bloomberg Politics, November 12, 2015.

Yermack, D., (1996). Higher market valuation of companies with a small board of directors. Journal of Financial Economics, 40, 185-212. 